\title{
أبرز صور الصراع بين السكنديين والأباطرة الرومان
} د/ أميرة قاسم الحدينى الاباطرة الرومان

مدرس بقسم الآثار والدراسات اليونانية والرومانية

كلية الآداب - جامعة الإسكندرية

ملخص البحث:

عانى الثعب السكندري في عهد الحكم الروماني لمصر من ظلم وانتقاص لحقوقهم بداية منذ

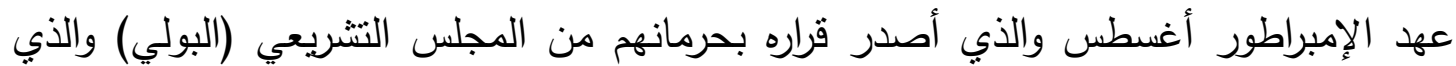
يمارس السكندريون من خلاله حقوقهم السياسية، واستمر السكندريون بعد أغسطس في المطالبة بحقوقهم وكانوا في البداية يلجأون إلى الالنتام بالسلمية ـ وهو ما حدث في عهر الأباطرة كاليجولا

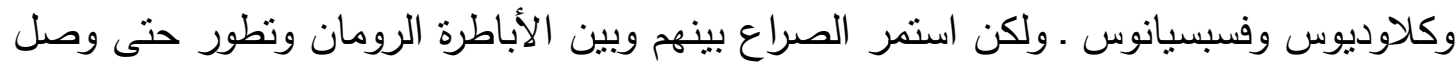

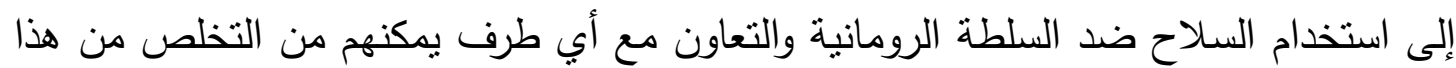

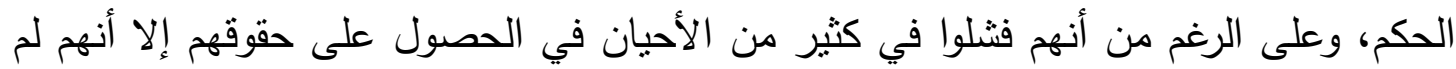
يستسلموا وظلوا يقاوموا هذا الحكم حتى النهاية.

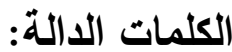
السكندريين- الأباطرة الرومان - اكتافيوس- الثورة السكندرية- أوريلليانوس.

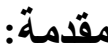

بعد سقوط دولة البطالمة في مصر ، وهزيمة الملكة كليوباترا، وحليفها القائد الروماني أنطونيوس

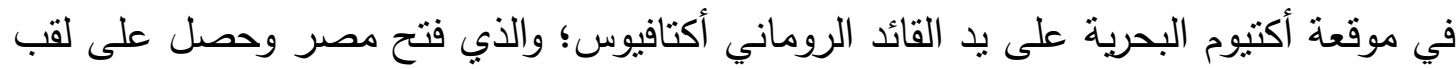

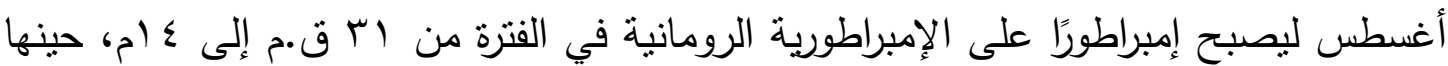

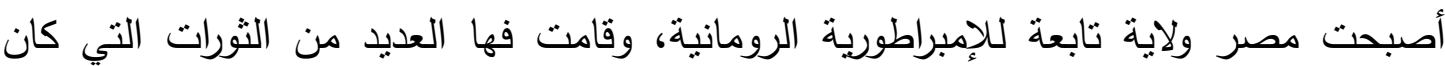

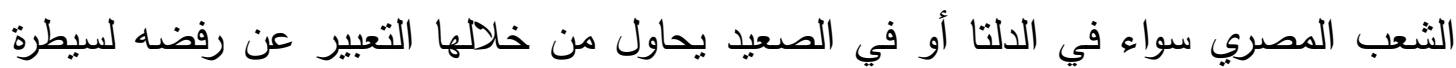
الحكم الروماني على مصر؛ وكانت تلك الثورات يتم قمعها بالقوة، وفي كثثر من الأحيان كانت تلك الثثرات مسلحة. شهدت الإسكندرية على وجه الخصوص الكثير من الصدامات والصراعات بين السكندريين والإدارة الرومانية (الحكم الروماني)، وحاول السكندريون التعبير بأكثر من طريقة

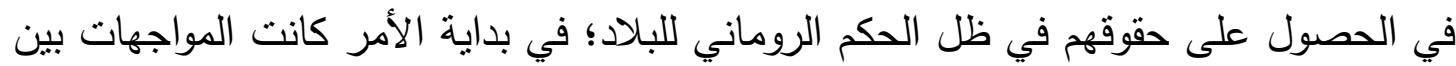
السكندريين والرومان في صورة ثورات (مواجهات) سلمية يطالبون فيها بحقوقهم التي أهدرها (حرمهم منها) بعض الأباطرة، وذلك منذ بداية عهد الإمبراطور أغسطس حتى نطورت هذرته الثورات (المواجهات) إلى الثورات المسلحة وهي الطريقة التي لجأ إليها السكندريون للحصول التصني

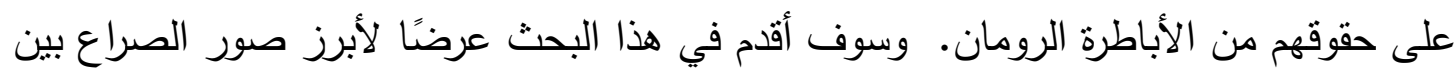


السكندريين، وبعض الأباطرة الرومان، والتي توضح نطور الصراع بين السكندريين والحكم

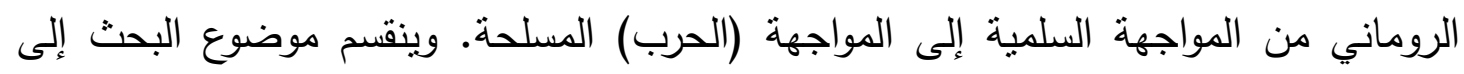
محورين:

- المحور الأول: وسوف أعرض فيه لأبرز المواقف السلمية التي حاول السكندريون من خلالها المطالبة بحقوقهم وتعرضهم لبعض الأباطرة في سبيل الحصول على تلألك الحقوق.

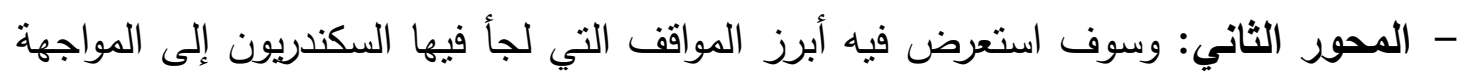
المسلحة مع الإدارة الرومانية (الأباطرة الرومان).

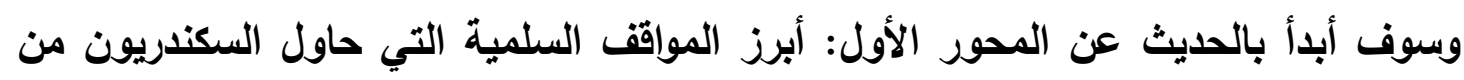

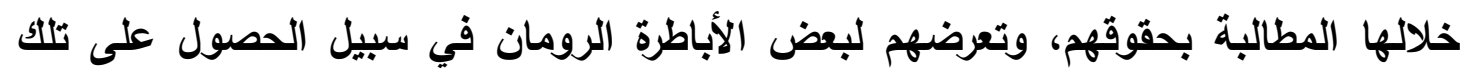

الحقوق:

كان السكنديون منذ عهد الدولة البطلمية يحصلون على الكثير من الامتيازات ويتمتعون بكثير

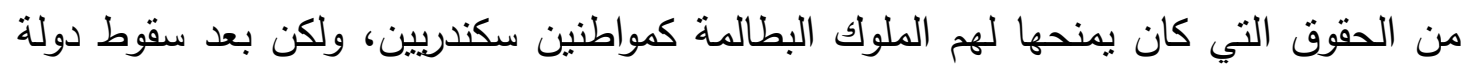

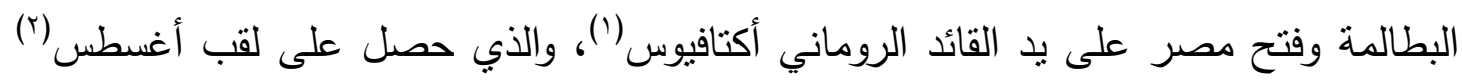

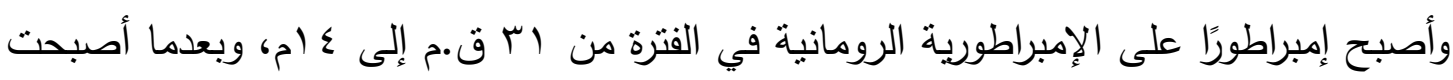

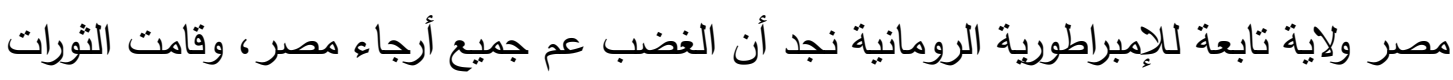

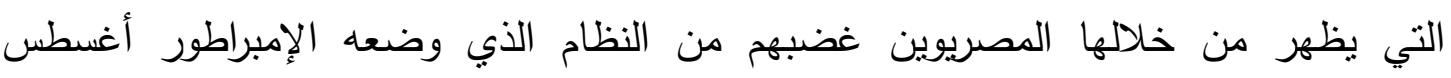

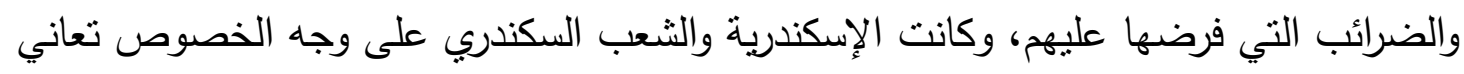

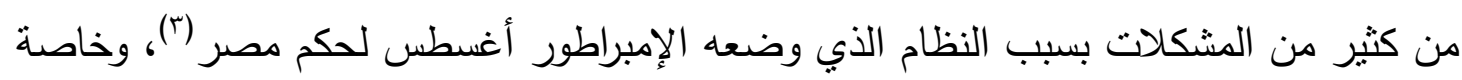

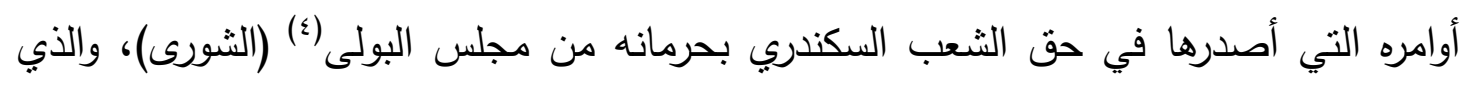

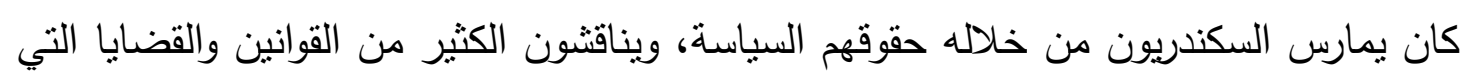

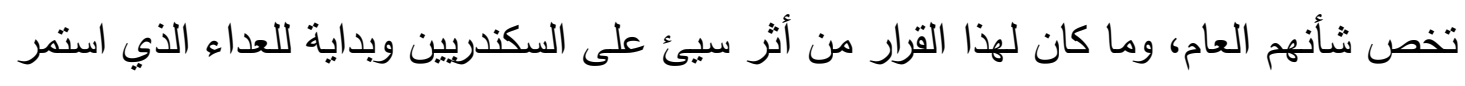
وتزايد على الحكم الروماني وما تم ترجمته في صورة مواجهات أو ثورات سلمية لجأ إليها

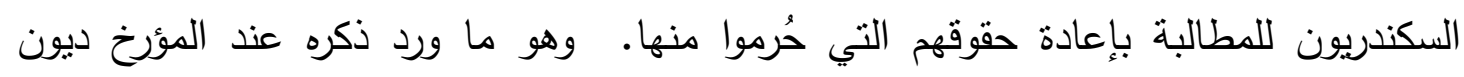

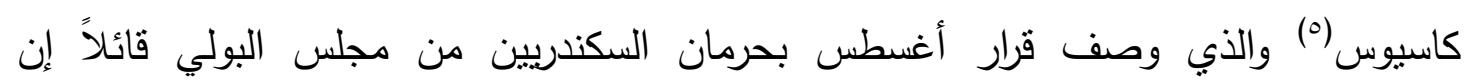
الإمبراطور أغسطس: "أمر السكندريين أن يدبروا شُئون مدينتهم دون مجلس نتشريعي (البولي)،

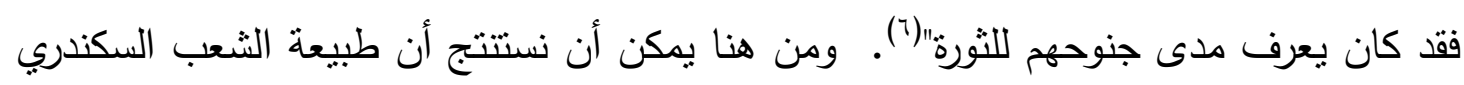
الساخر والثائر هي التي كانت سببًا في حرمانهم من كثير من حقوقهم من جانب الإمبراطور

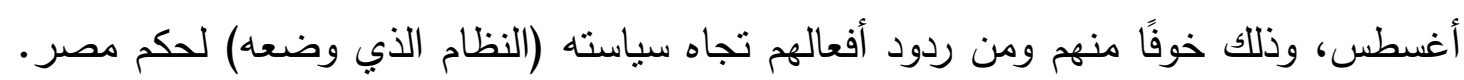
وليس هذا فحسب هو الذي أغضب السكندريون من الإمبراطور أغسطس، ولكن هناك مثالاً آخر

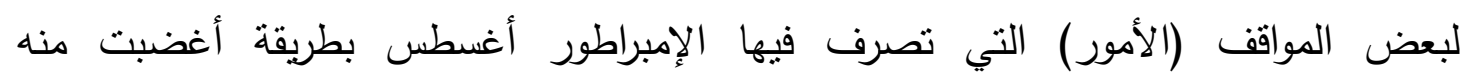


السكندريين؛ فعلى سبيل المثال أنه (أغسطس) عندما رأى جثمان الإسكندر ولمسه بالفعل، عند

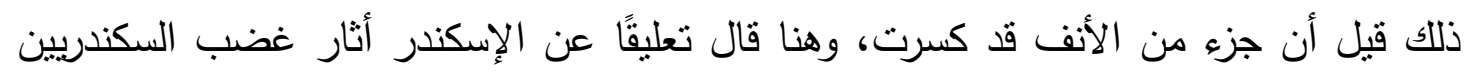

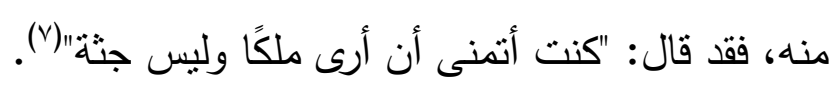

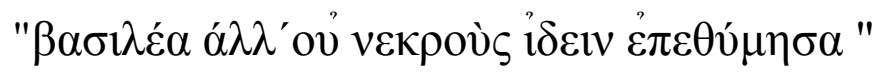

وهنالك مثالاً آخر، عندما لم يحضر لروئة تمثال العجل أبيس موضحًا "أنه اعناد على عبادة

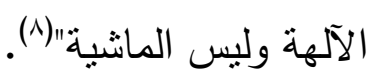

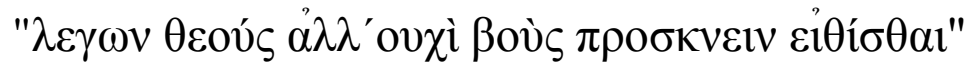

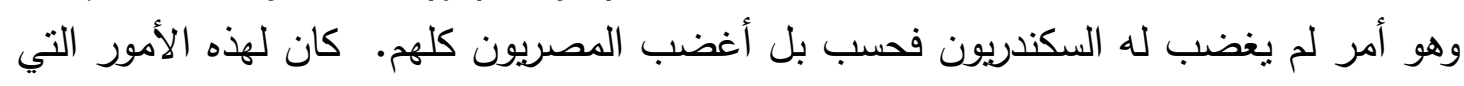

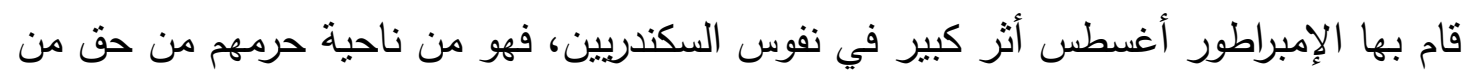

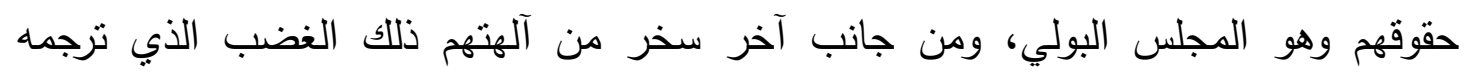

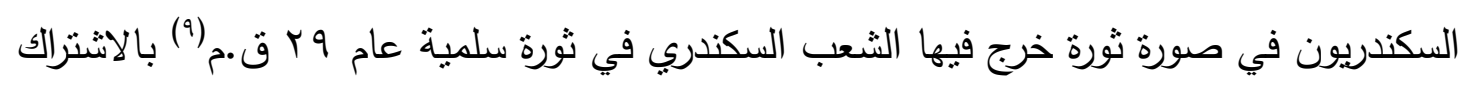

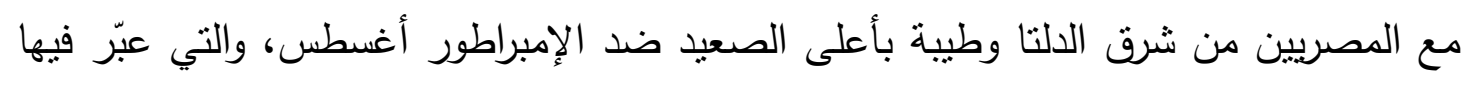

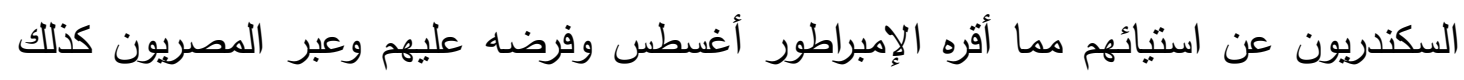

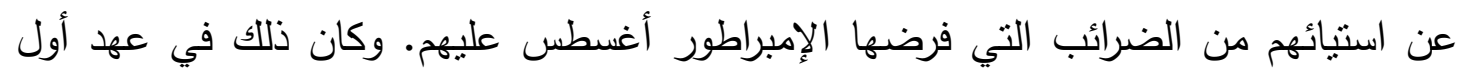

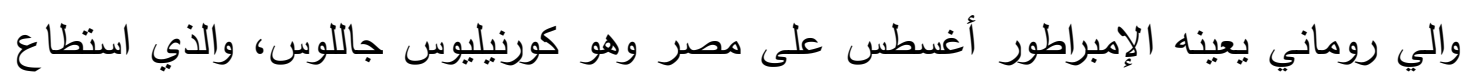

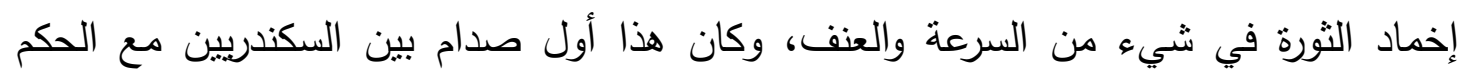

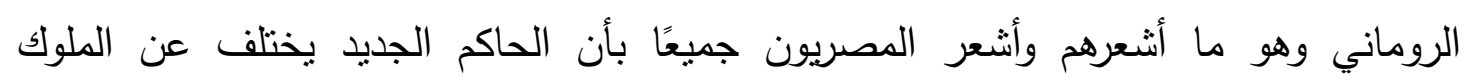

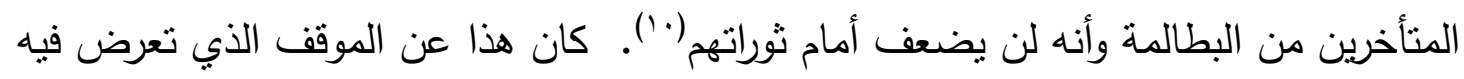

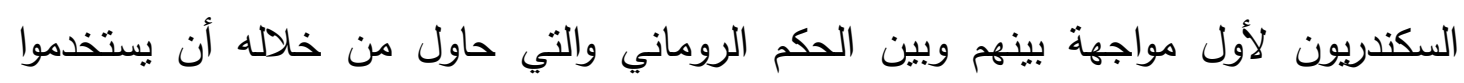

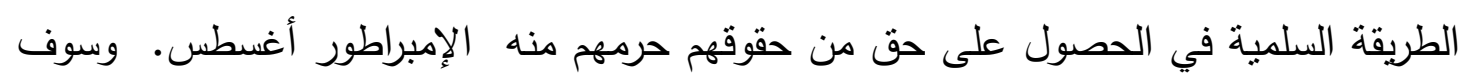

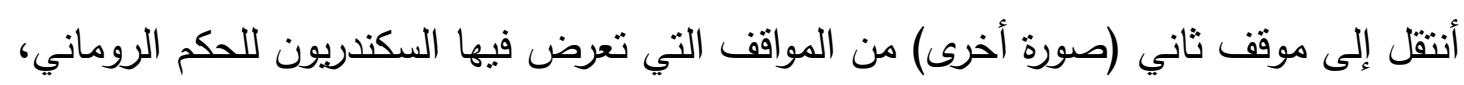

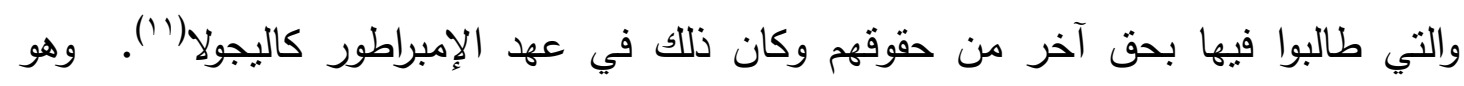

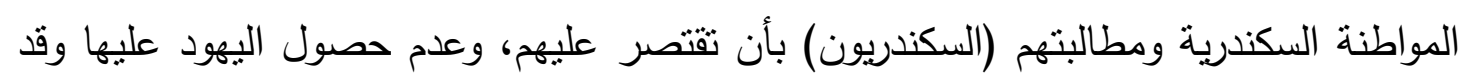

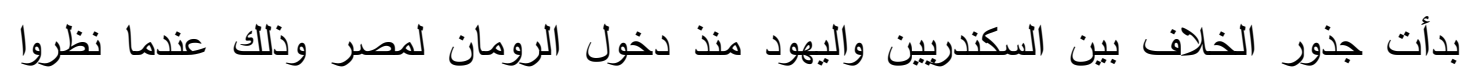

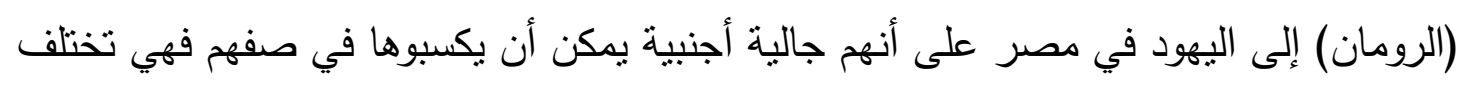

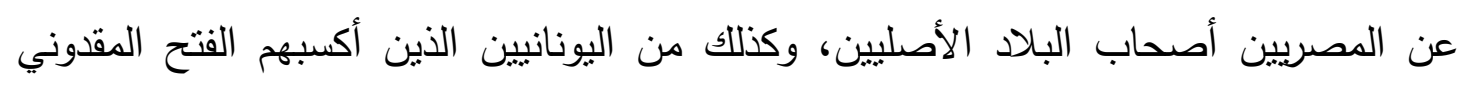

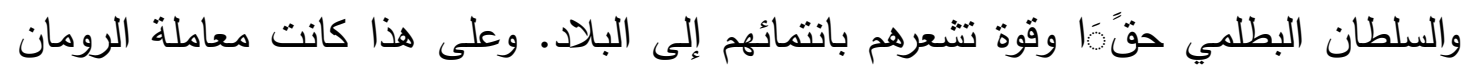

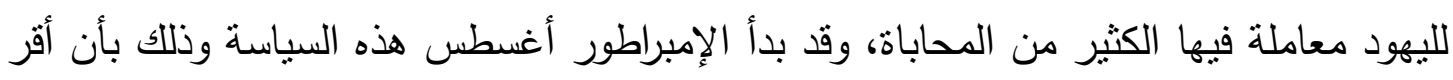

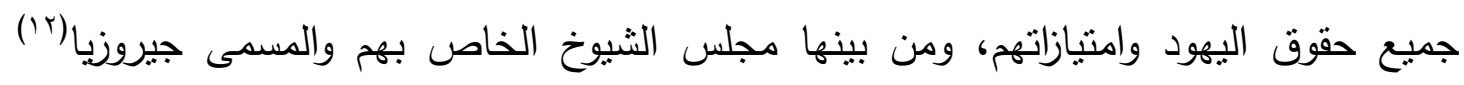

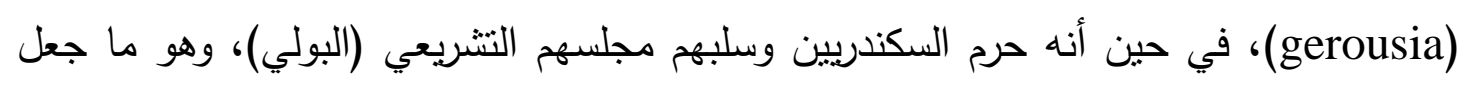


السكندريون يضيقوا بهذا النظام الحاكم (الروماني) إلا أن اليهود لم يقنعوا بما حصلوا عليه من مميزات منذ عصر أغسطس وحاولوا أن يزيدوا من هذه المميزات فادعوا لأنفسهم مواطنة

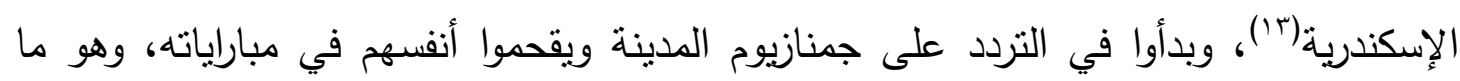

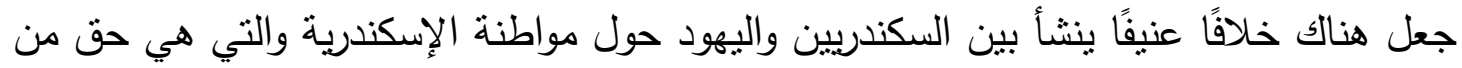

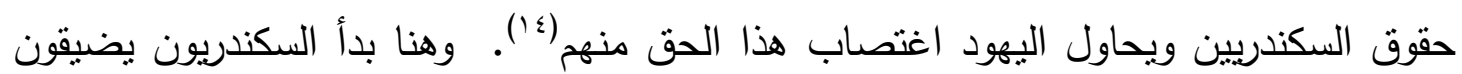
بموقف اليهود ومساندة الرومان لهم فبدوا يحاولون الدفاع عن حقهم في مواطنة الإسكندية

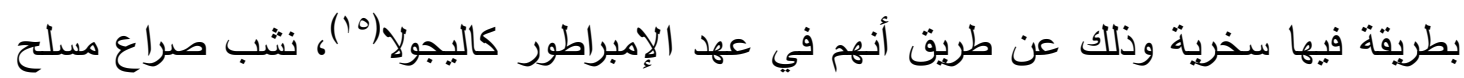

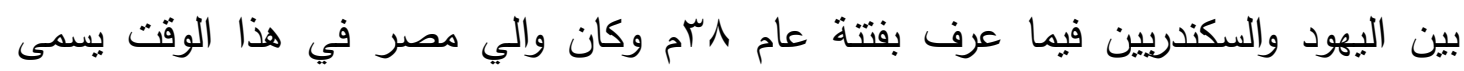
فلاكوس؛ وذلك عندما مر بالإسكندرية الملك اليهودي أجريبا، والذي كان قد نصبه الإمبراطور

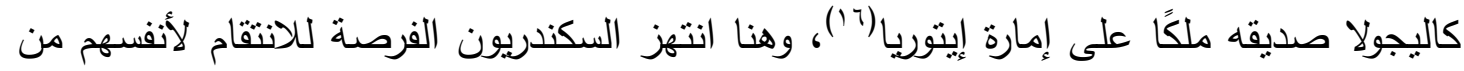

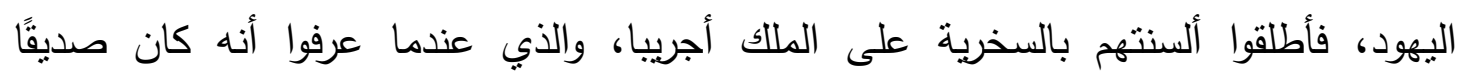

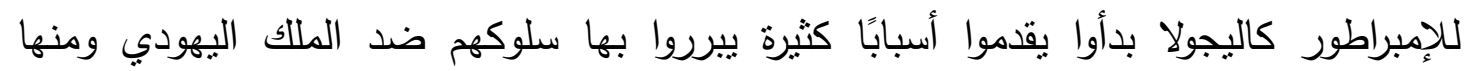

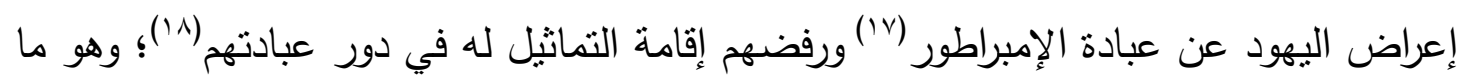
جعل السكندريون يقتحمون دور عبادة اليهود محاولين إقامة تماثيل للإمبراطور بها وهو ما عاديا

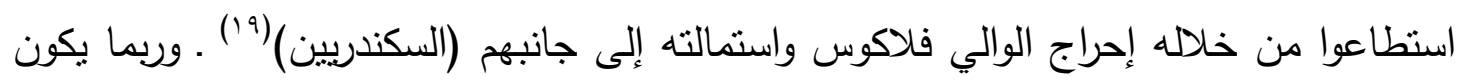

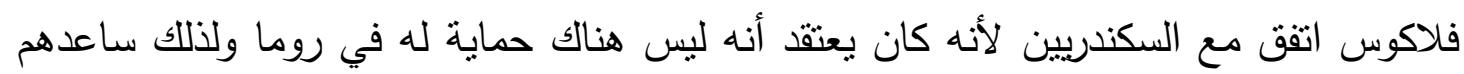

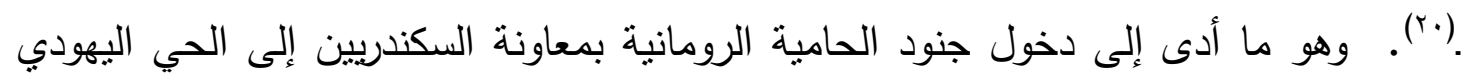

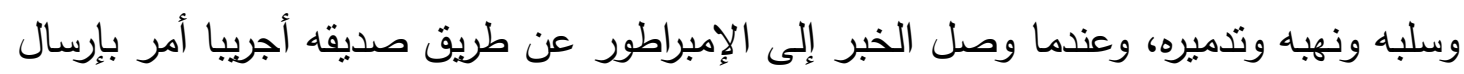

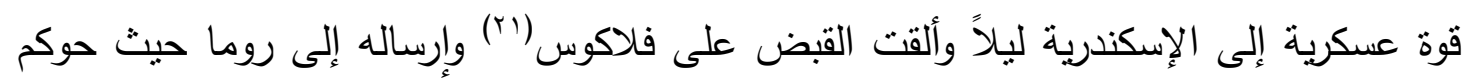

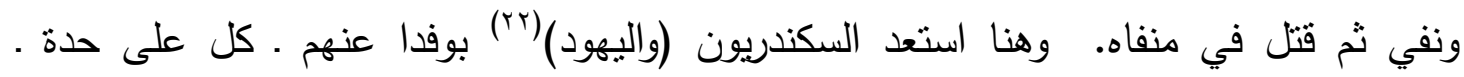

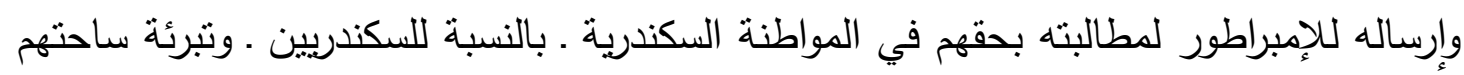

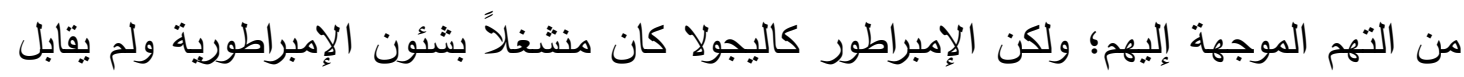
الوفدين السكندري أو اليهودي وبذلك لم تحل مشكلة السكندريين في عهد الإمبراطور كاليجولا.

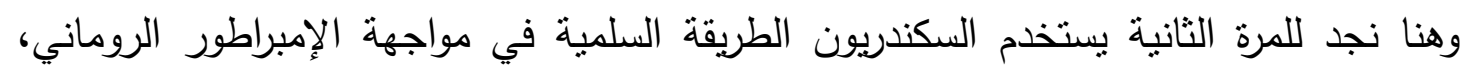

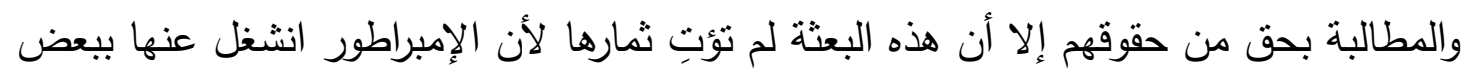

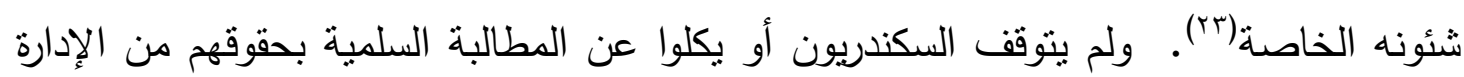

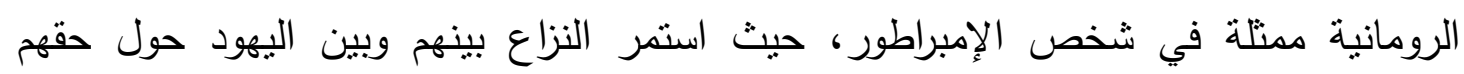

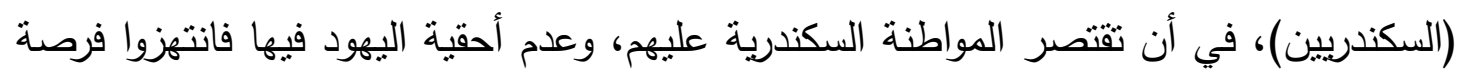

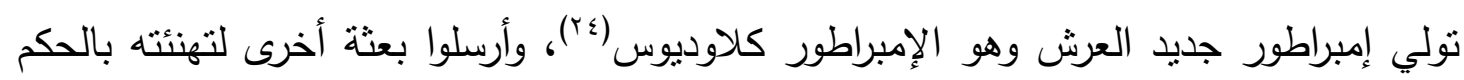
وعرض قضيتهم عليه ـ وكذلك اليهود فعلوا الثيء ذاته ـ وهو ما يمكن اعتباره الموقف الثالث 
الذي قام فيه السكندريون باستخدام الطرق السلمية في مواجهة الدولة الرومانية للحصول على فلى

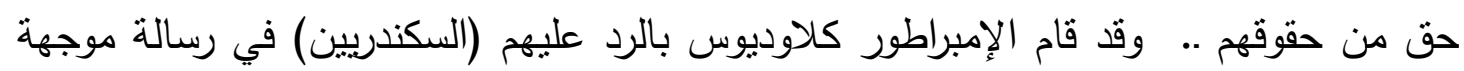

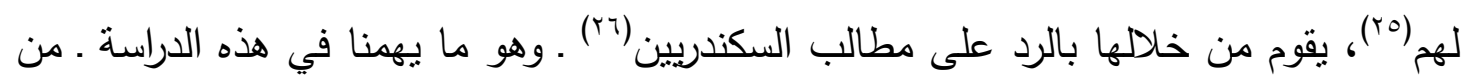

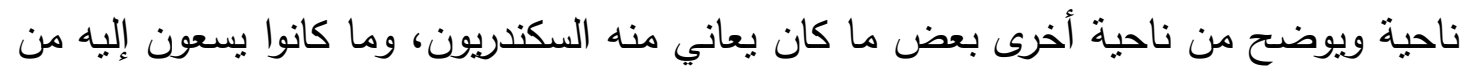

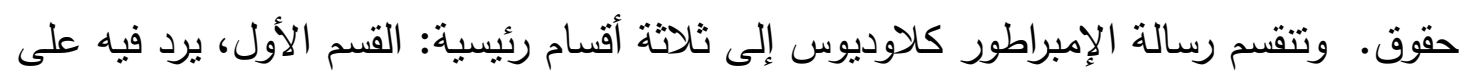

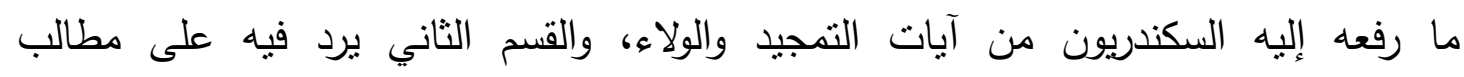

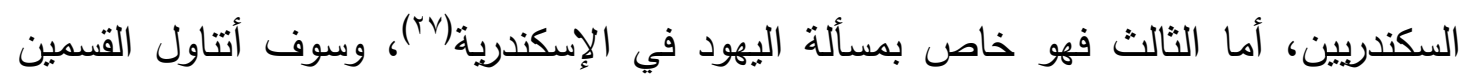

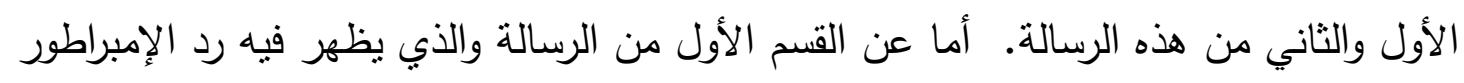

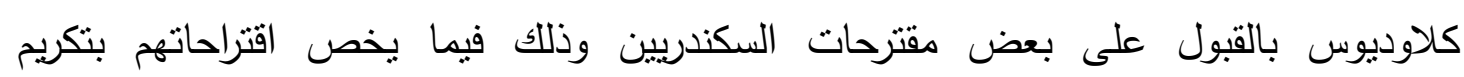
الإمبراطور وتمجيده، وذلك عن طريق الاحتفال بعيد ميلاده، وإقامة تماثيل له ولأفراد أسرته في بعني

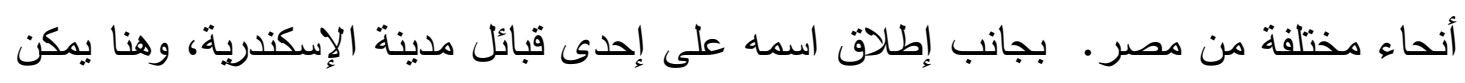

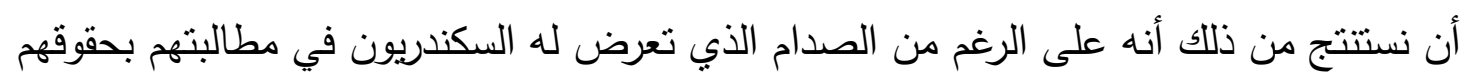

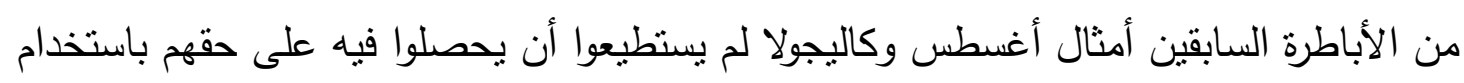

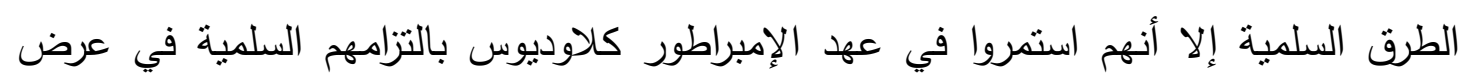

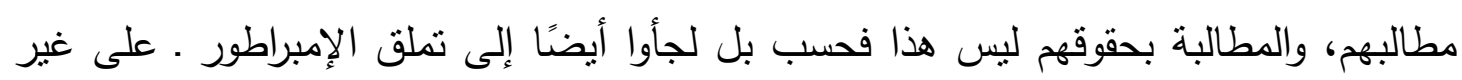

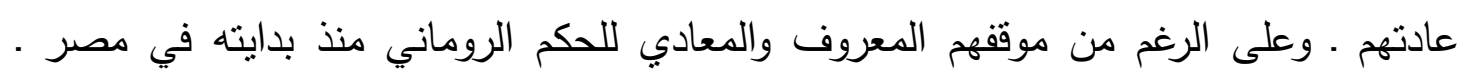

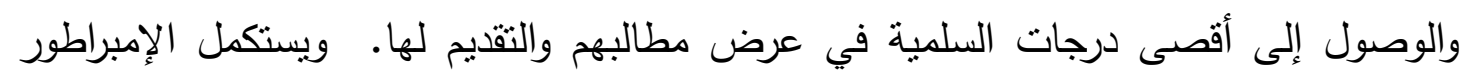

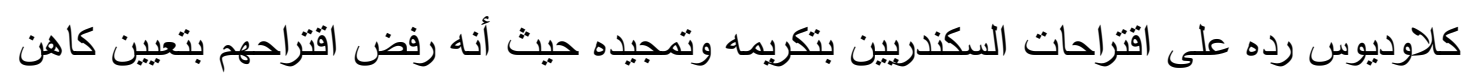
خاص لعبادته وإقامة معبد خاص لذلك وهو ما يوضح إلى أي مدى كانت شخصية الإمبراطور كلاوديوس تتسم بالاتزان والتعقل حتى أنه لم يضعف أمام هذا التملق والمديح السكندري. وينتقل

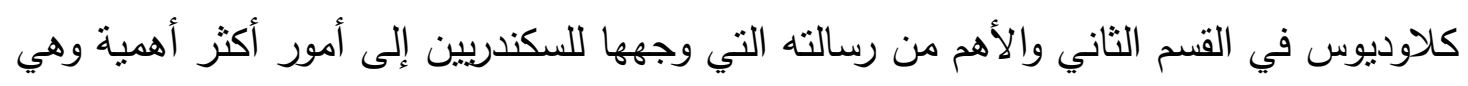

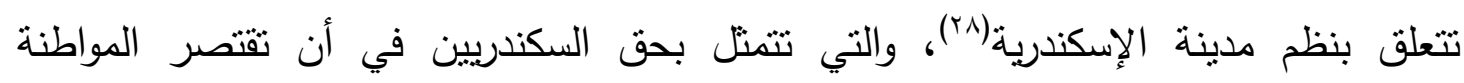

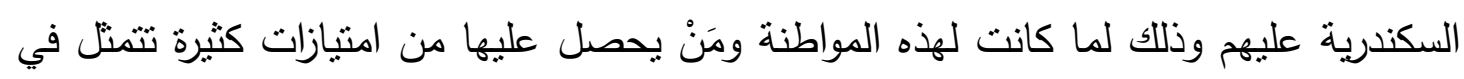

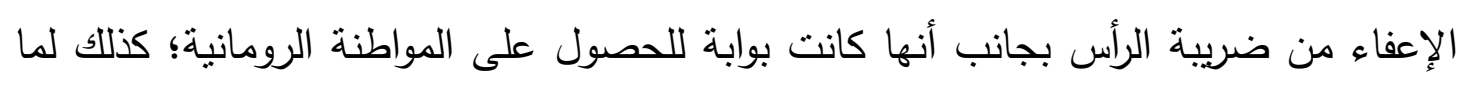

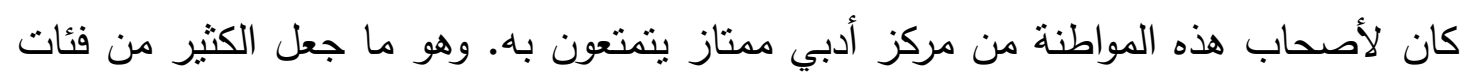

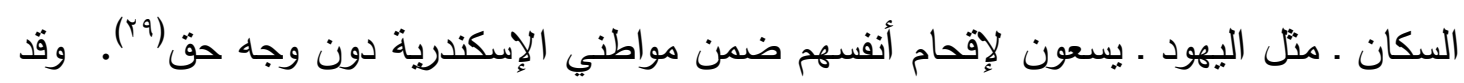

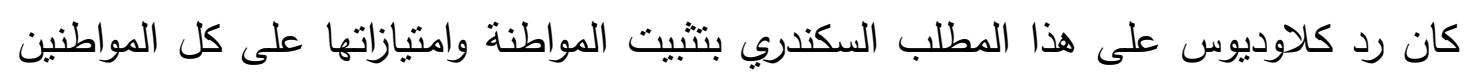

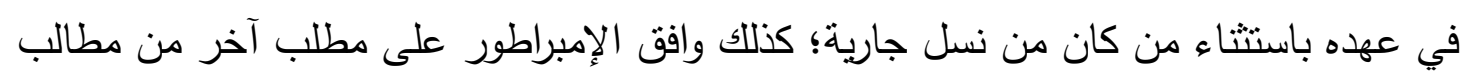

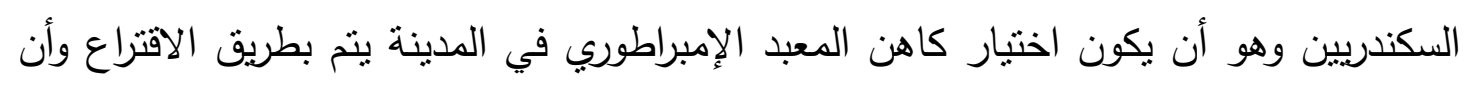

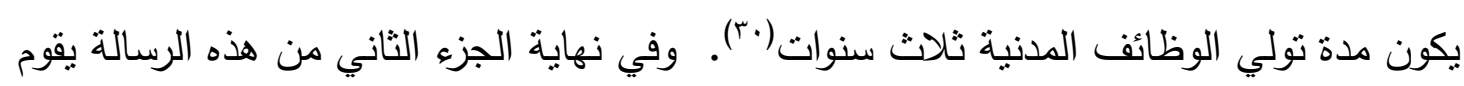


الإمبراطور بالرد على مطلب وحق هام وأساسي بالنسبة للسكندريين طالما سعوا للحصول عليه منذ عهد الإمبراطور أغسطس وهو عودة المجلس التشريعي للمدينة("). . وهنا نجد الإمبراطور كلاوديوس يلتزم الحرص والحذر في رده على السكندريين فيما يخص هذا المطلب، وخاصة انه

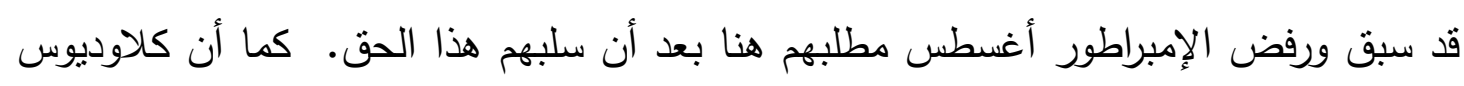

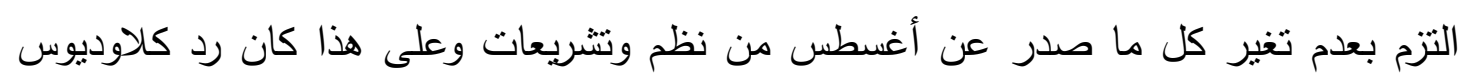

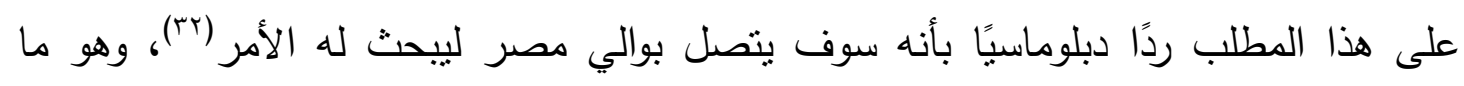

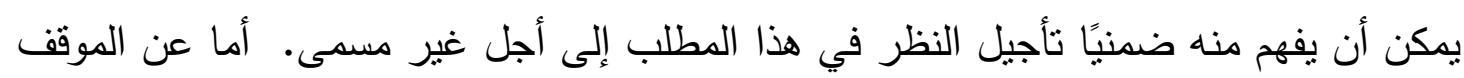
العدائي من السكندريين لليهود فقد أصدر الإمبراطور كلاوديوس أوامره للسكندريين بألا يقوموا

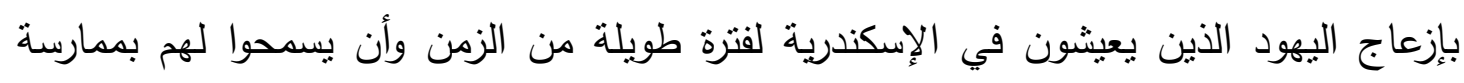

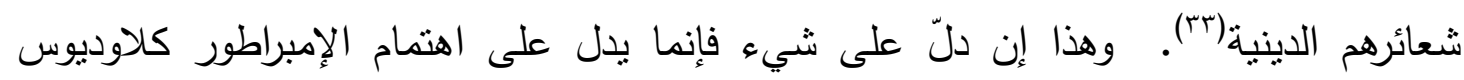

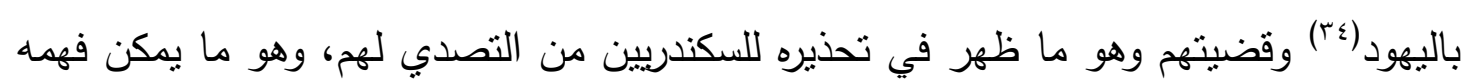

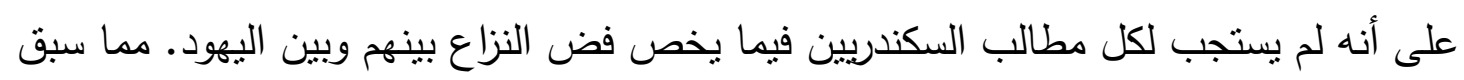

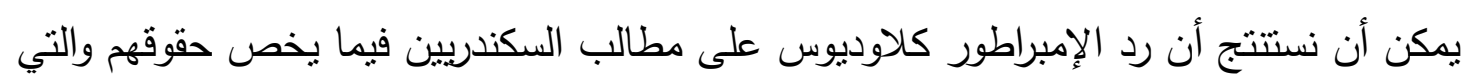

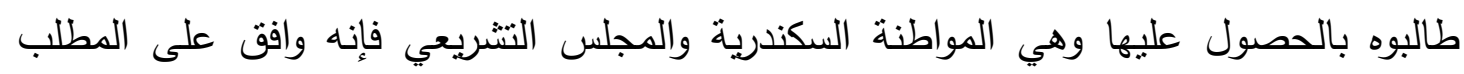

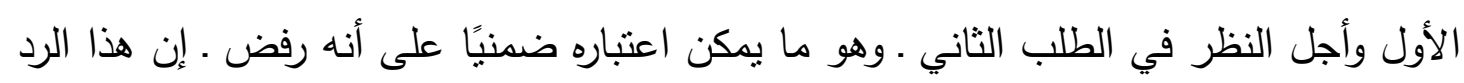

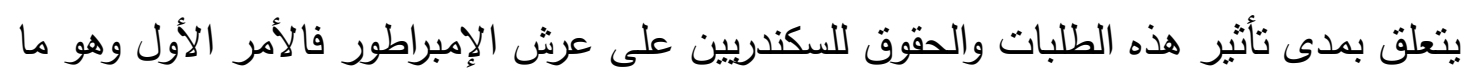

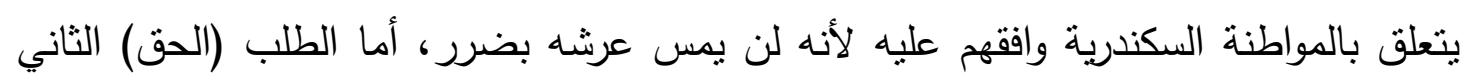

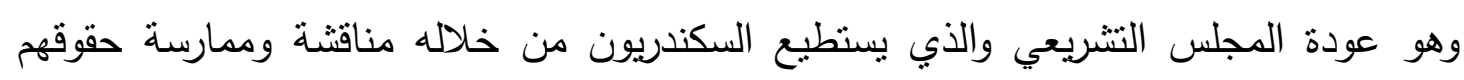

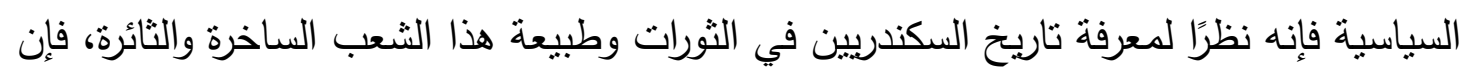

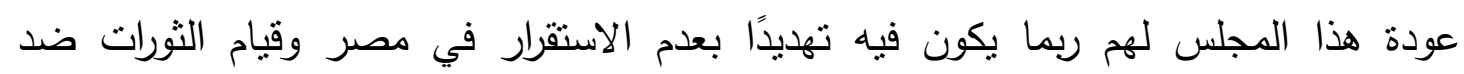
الإمبراطور، وربما كان الإمبراطور أغسطس فيما اتخذه من قرار سابق بحرمانهم (السكندريين)

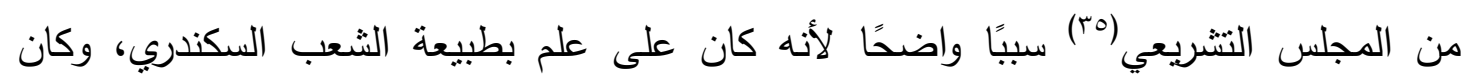

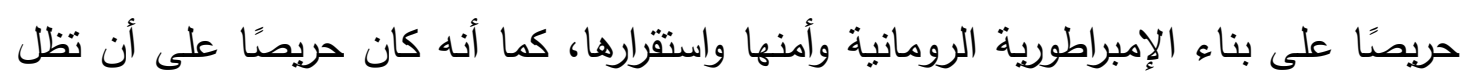

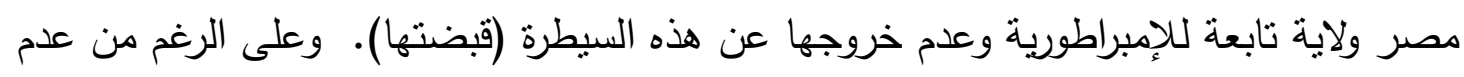

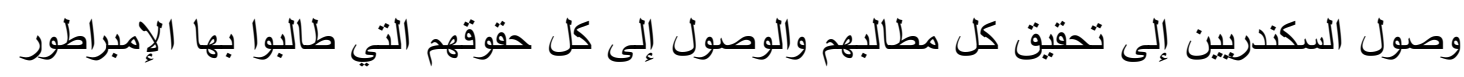

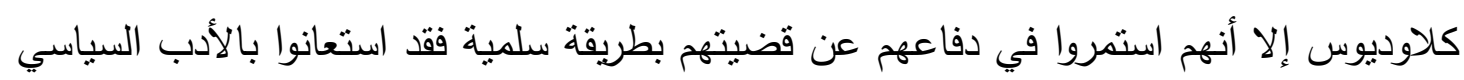

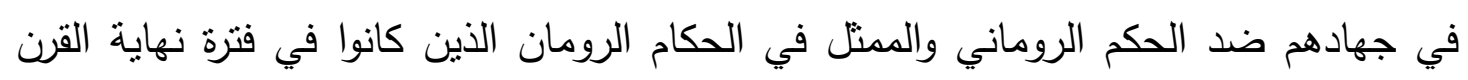

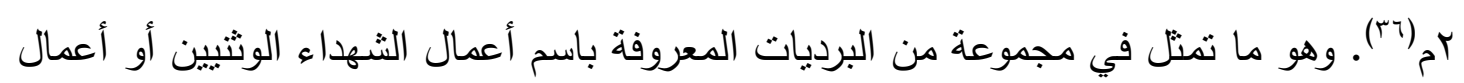

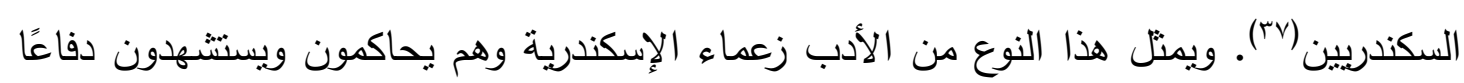

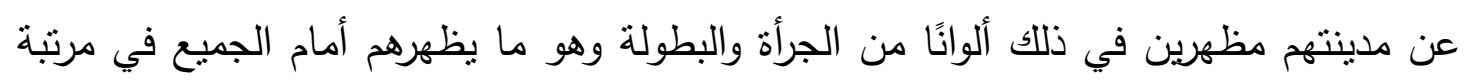


الثهاء من أصحاب المبادئ، وهناك على سبيل المثال نجد بردية يظهر فيها اثثين من زعماء

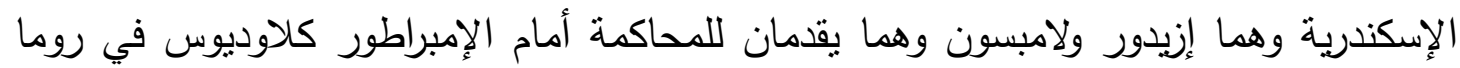

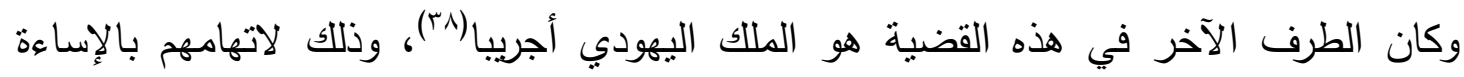

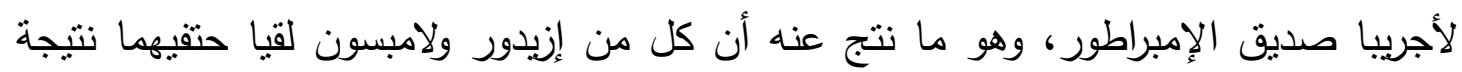

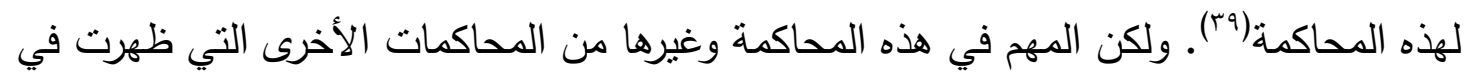

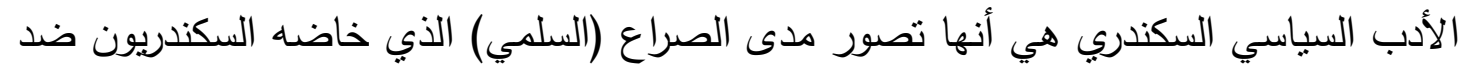

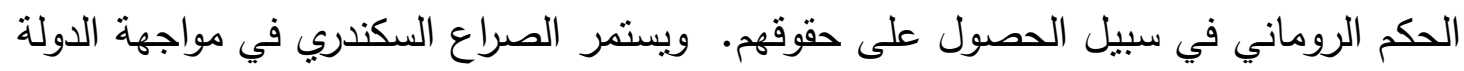

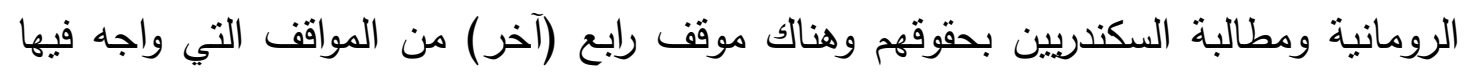

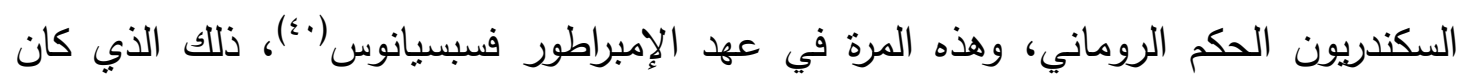

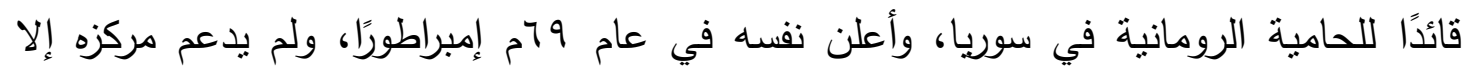

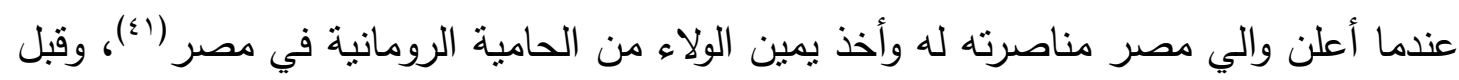

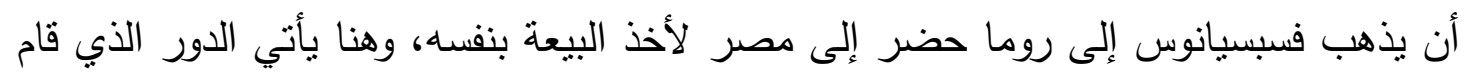

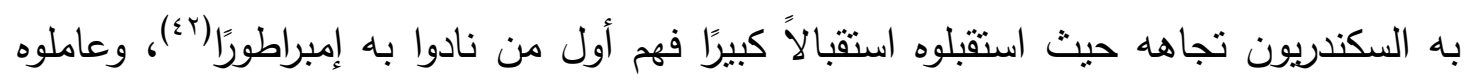

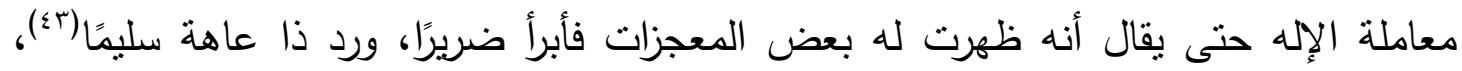

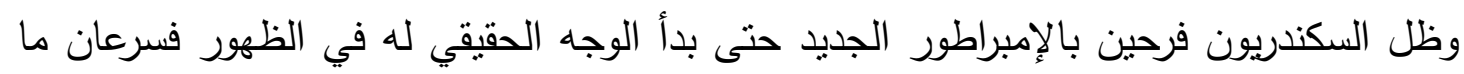

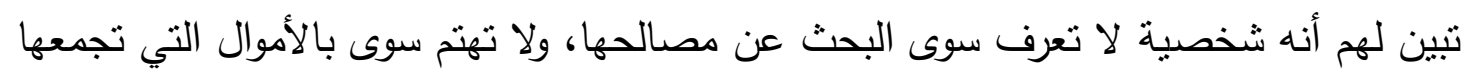
لخزائن الدولة. فقد قام بتحصيل (جمع) مبالغ ضخمة من السكندريين بطرق مختلفة متغاضيًا

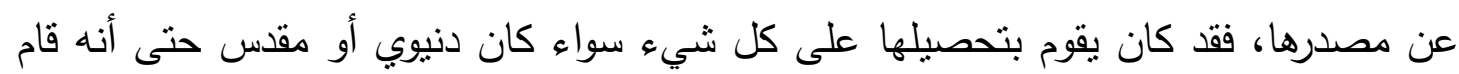

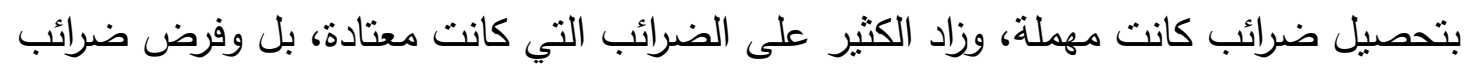
أخرى جديدة(๕)، وهو ما ظهر في أحد المواقف التي قام فيها الإمبراطور بنفسه بمطالبته أحد

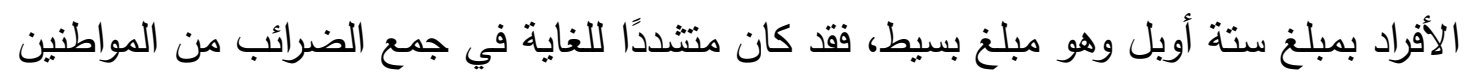

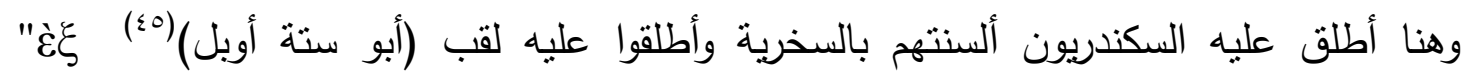
"

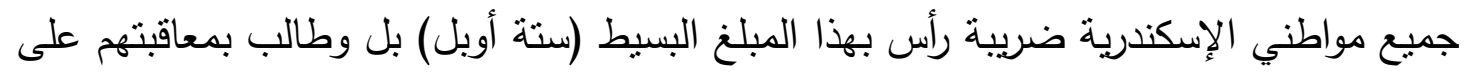

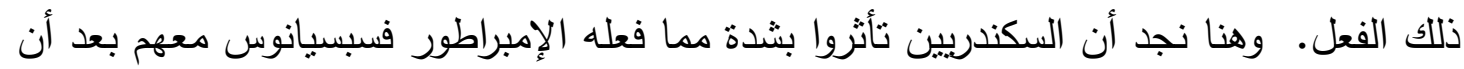

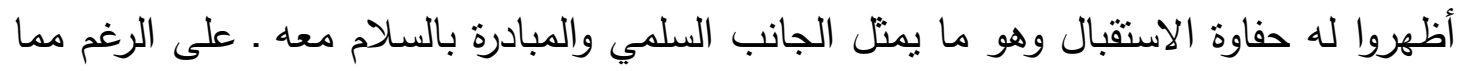

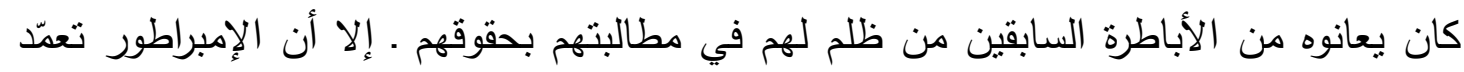

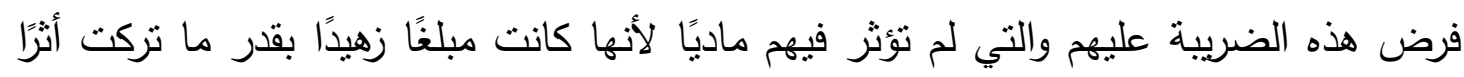

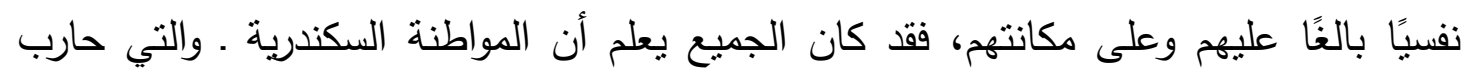
السكندريون لجعلها قاصرة عليهج ـ تعفي أصحابها من ضريبة الرأس وكانوا يعتزون بهذا الامتياز 
إلا أنها ظلت حتى قام تيتوس ابن الإمبراطور بمخاطبة والده فسبسيانوس لإلغاء هذه الضريبة

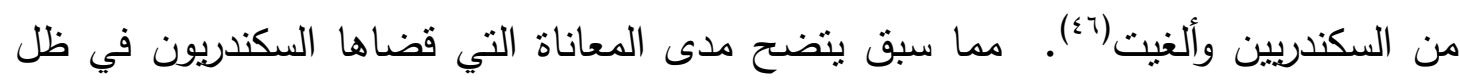

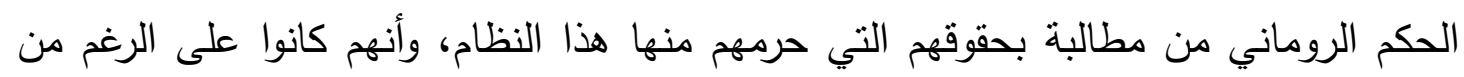

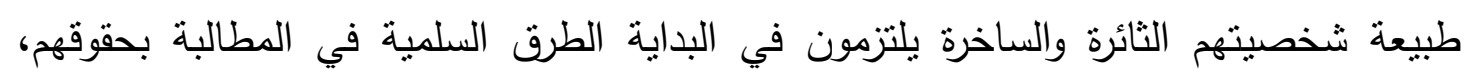

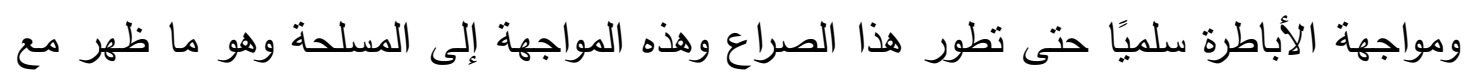

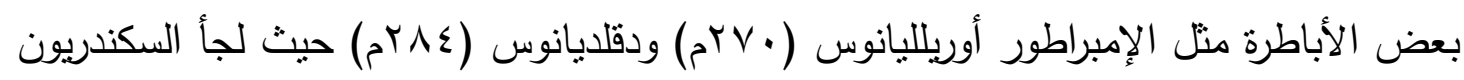
إلى رفع السلاح في وجه الحكم الروماني واستخدام العنف، وهو ما ظهر في الفترة من أواخر

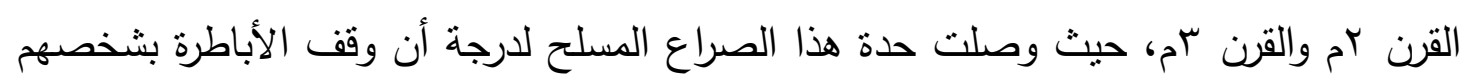

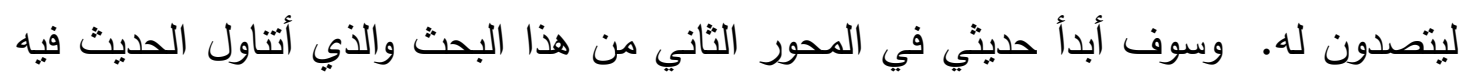
عن أبرز المواقف التي استخدم فيها السكندريون السلاح في وجه الحكم الروماني (الأباطرة) للمطالبة بحقوقهم وسأبدأ فيها:

أ- بالحديث عن الثورة السكندرية في عهد الإمبراطور أوريلليانوس:

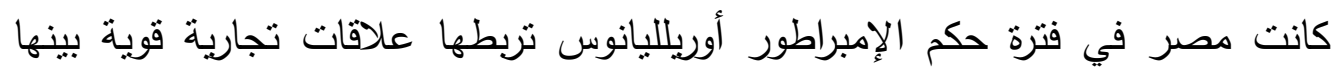

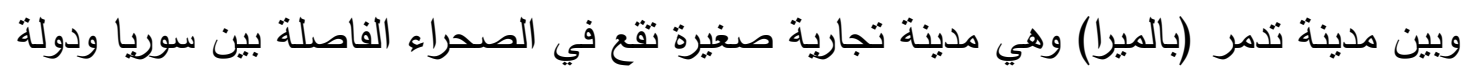

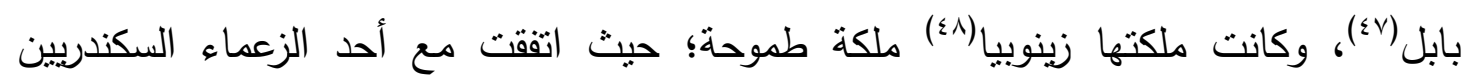

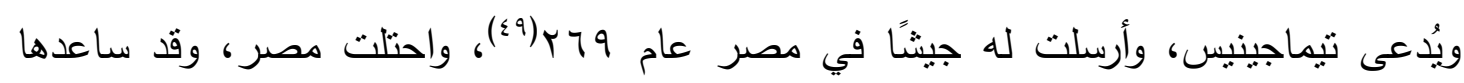

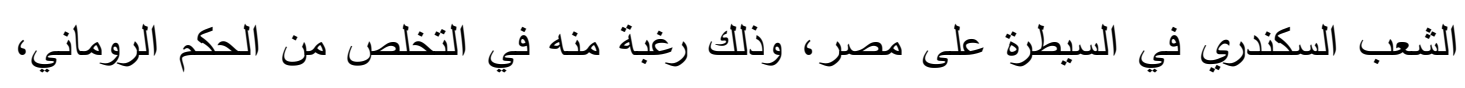

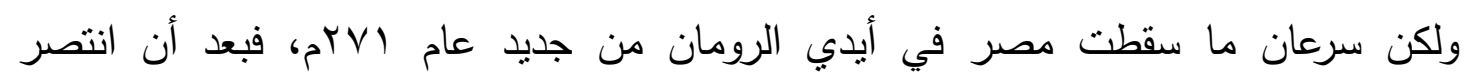

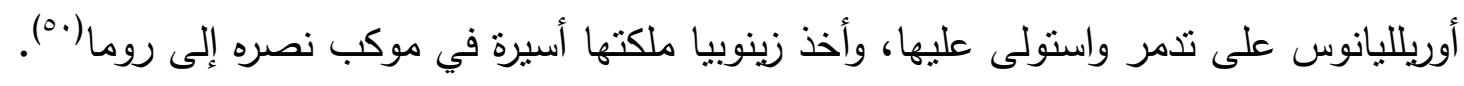

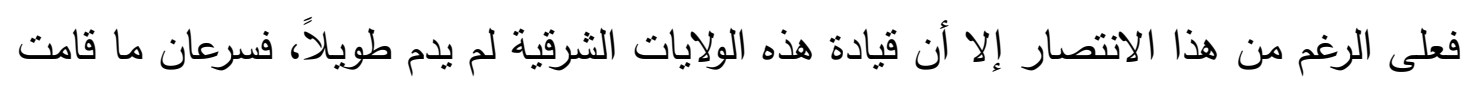

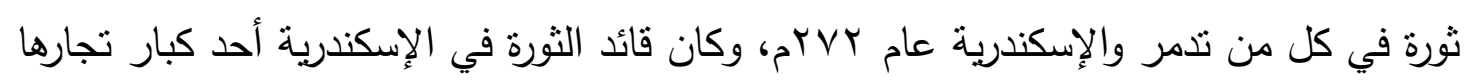

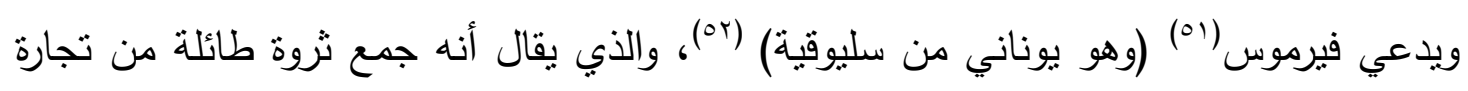

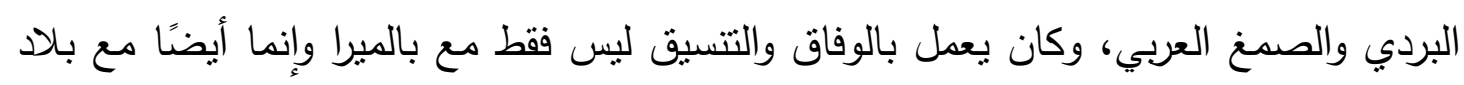

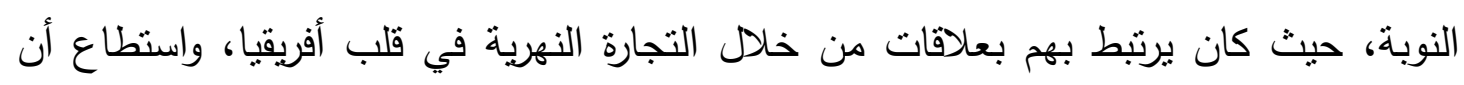

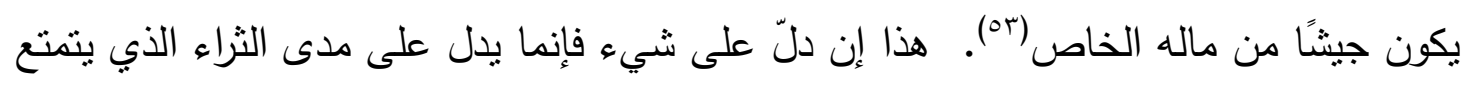

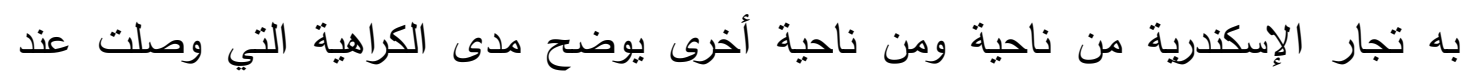

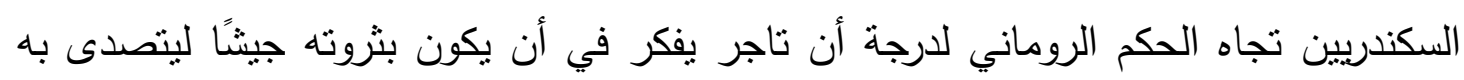

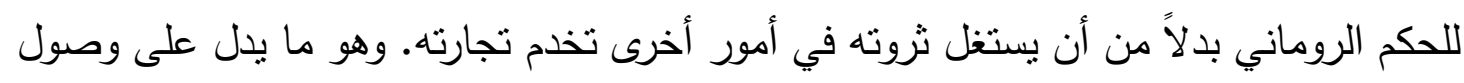

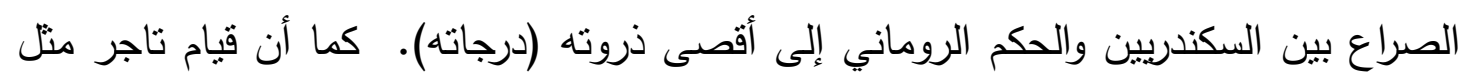

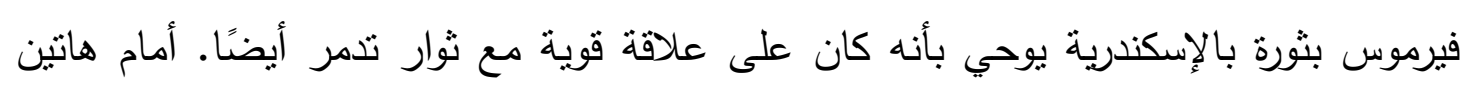


الثورتين اللتين قامتا في كل من الإسكندرية وتدمر في آن واحد، فإننا نجد أن الإمبراطور

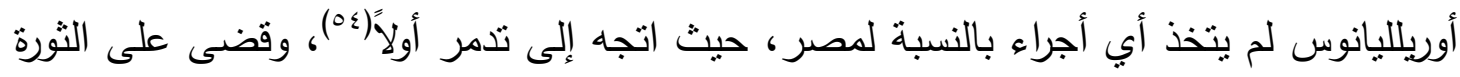

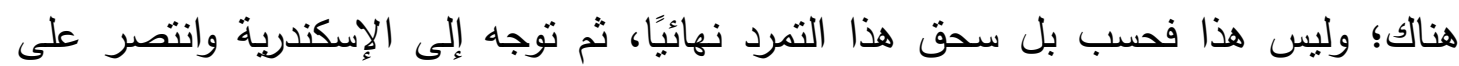

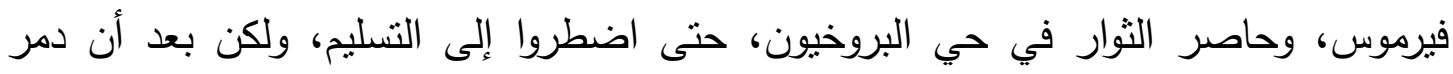

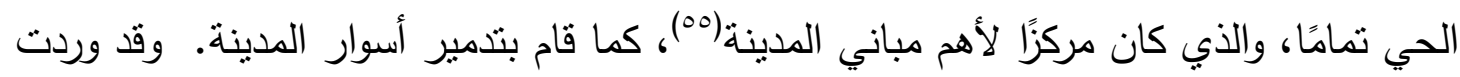

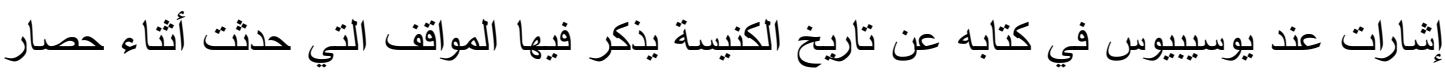

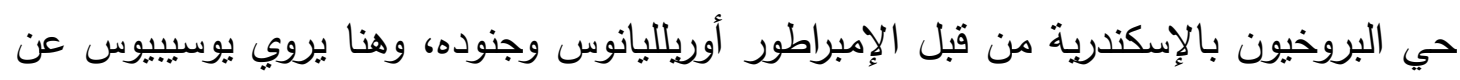

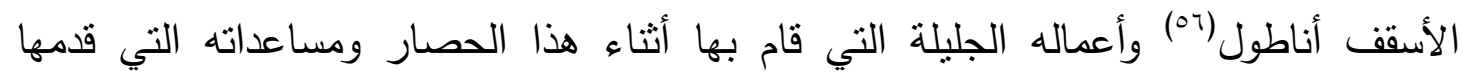

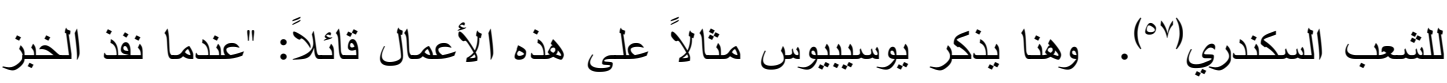

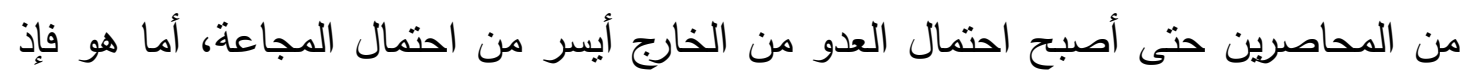

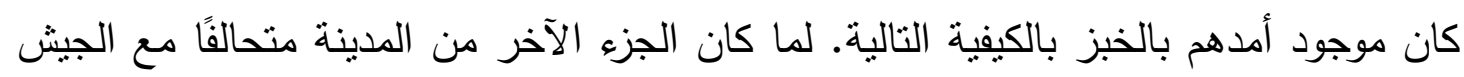

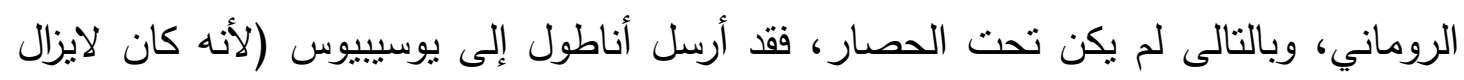

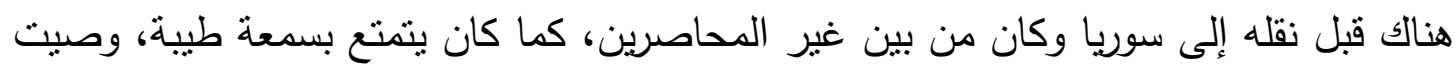

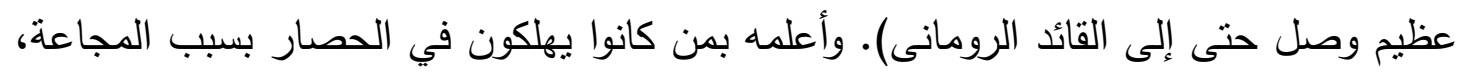

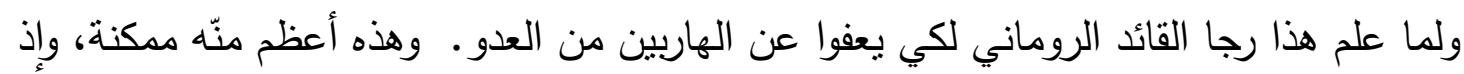

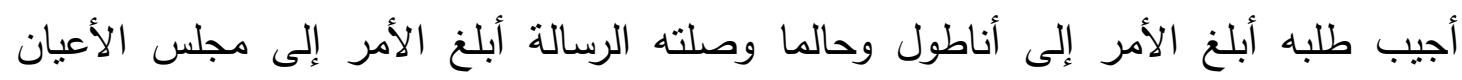

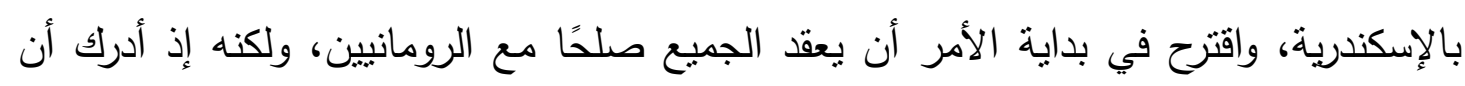

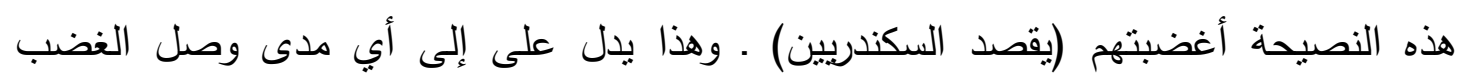

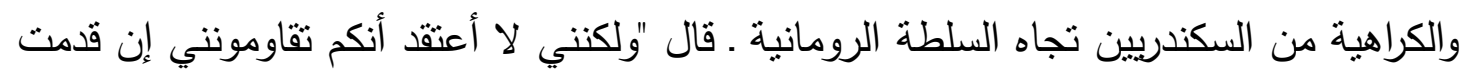

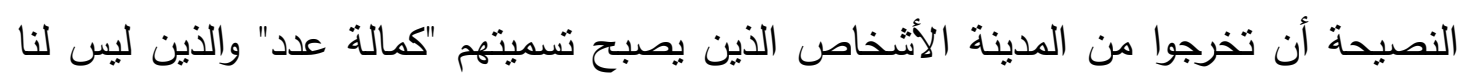

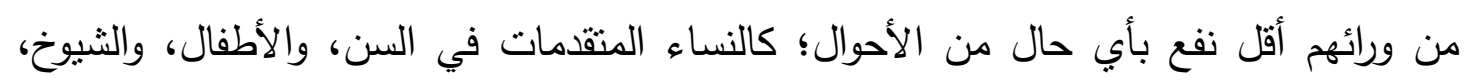

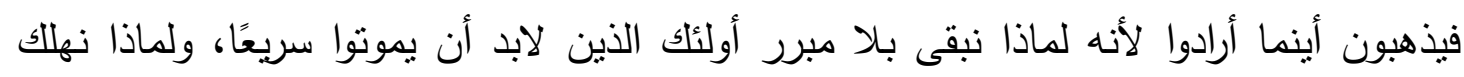

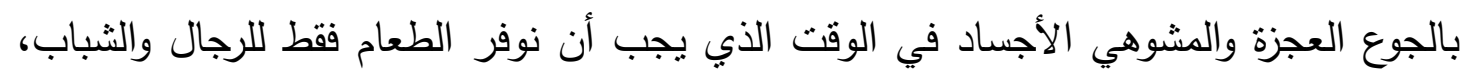

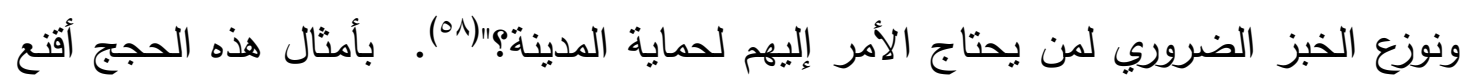

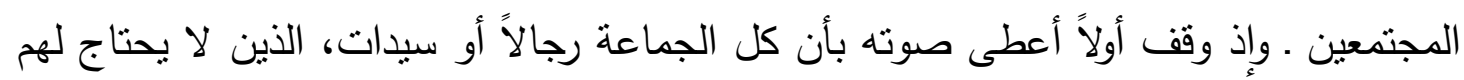

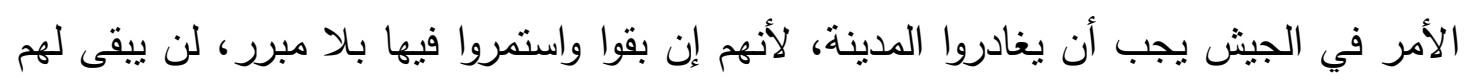

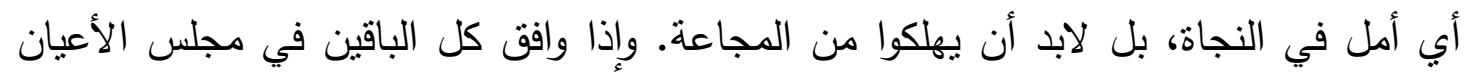

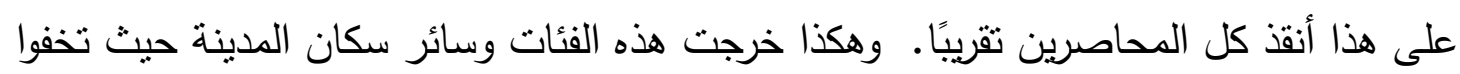

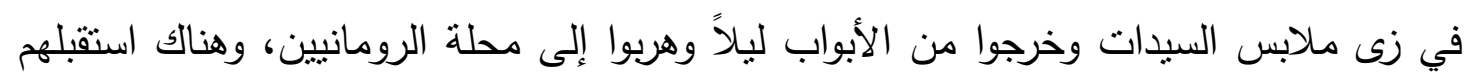

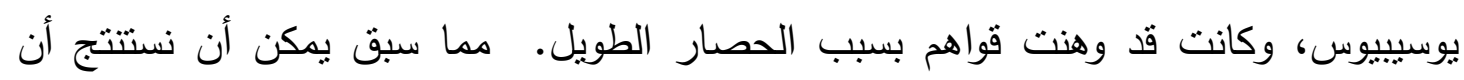


السكندريين قد تحملوا الحصار وعذابه عن أن يستسلموا للرومان، فقد سبق وأن استعملوا الطرق

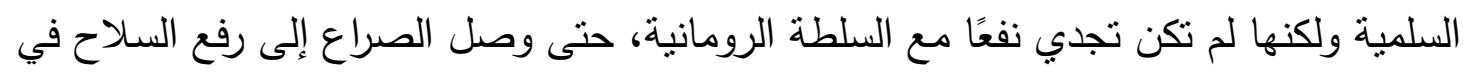

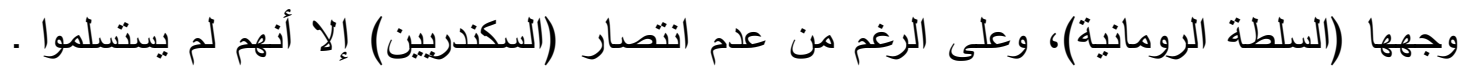

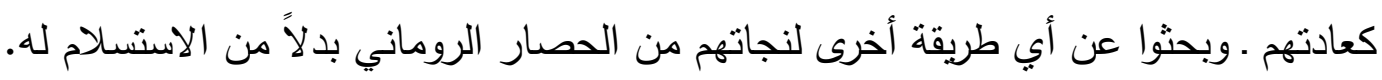

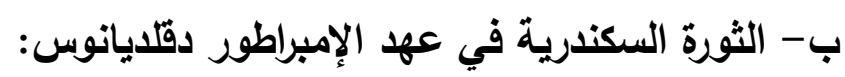

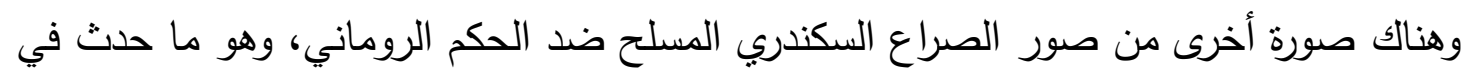

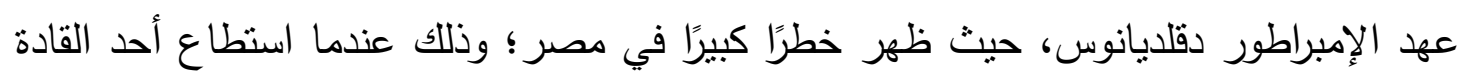

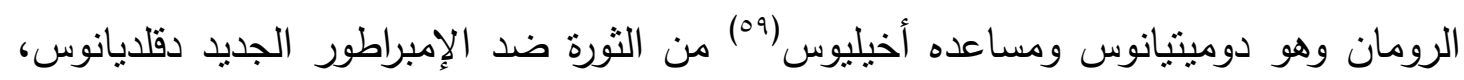

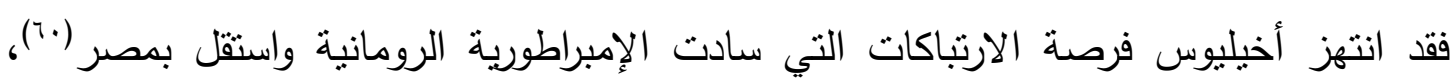

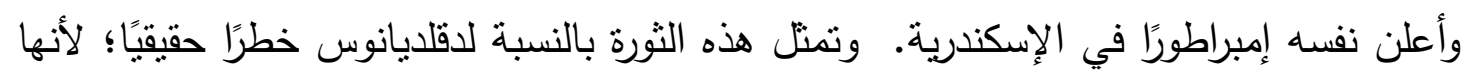

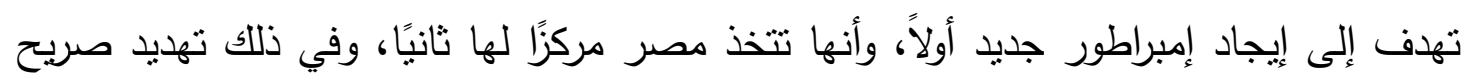

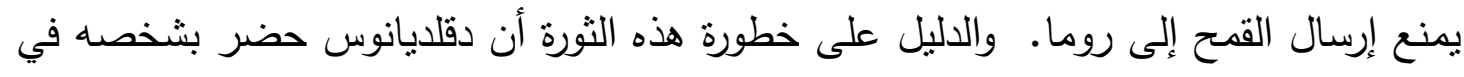

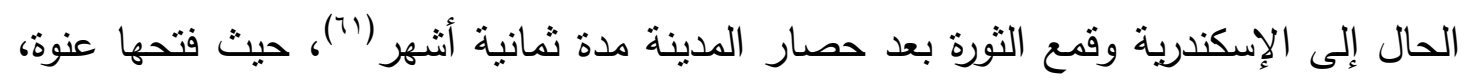
واستولى عليها فأحرق ودمر أجزاء كثيرة منها. ويبدو أن الحالة في المدينة كانت سيئة جدًا حتى التى

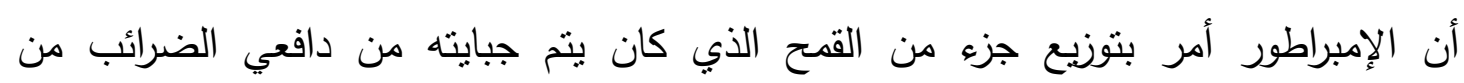

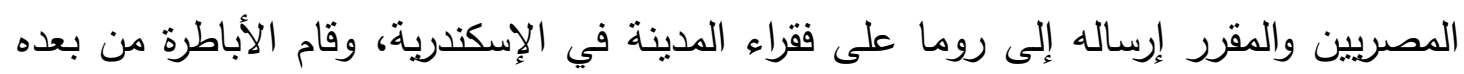

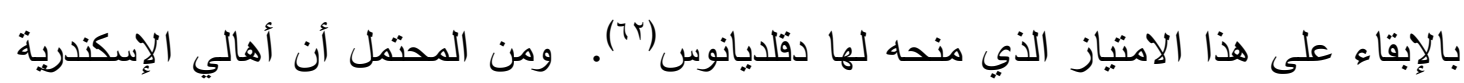

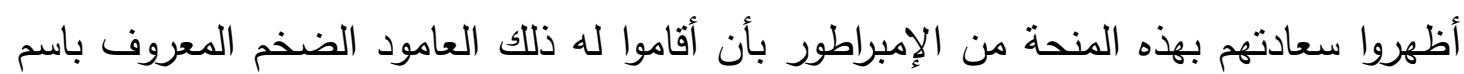

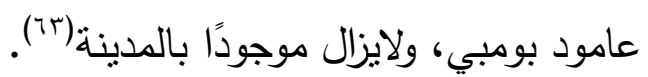


منذ فتح مصر على يد القائد الروماني أكتافيوس والذي لُقب بأغسطس عقب موقعة أكتيوم

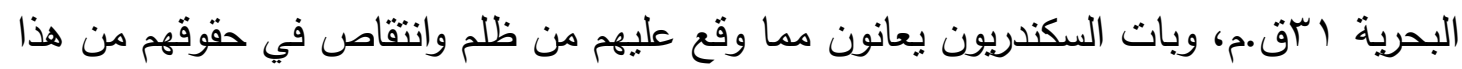

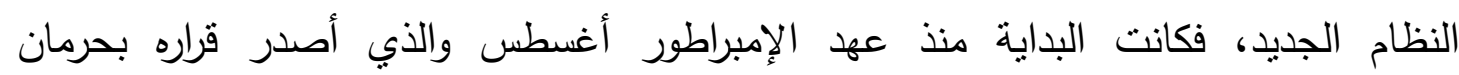
السكندريين من المجلس النتريعي (البولي) والذي يمارسون من خلاله حقوقهم السياسية ثم توالت معاناة الثعب السكندري في فقدان حقوقه وهو ما حدث من خلال مطالبة اليهود بمشاركة

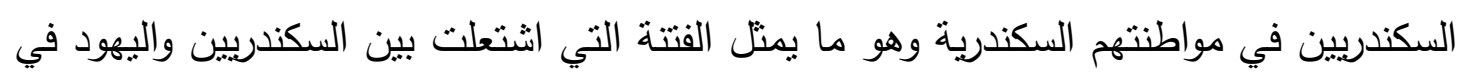
عهر الإمبراطور كاليجولا واستمرت في عهد الإمبراطور كلاوديوس وفي البداية وطوال هذه الفترة كان السكندريون يلتزمون بالسلمية في المطالبة بحقوقهم من النظام الحاكم (الدولة الرومانية)،

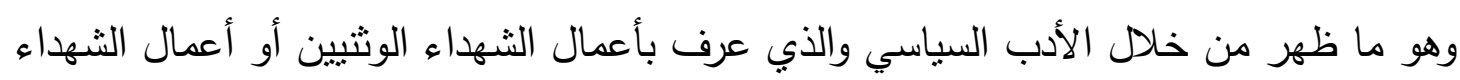

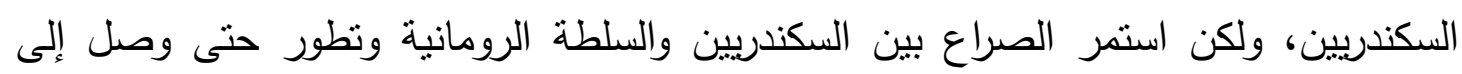

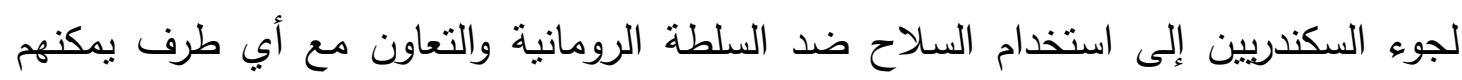

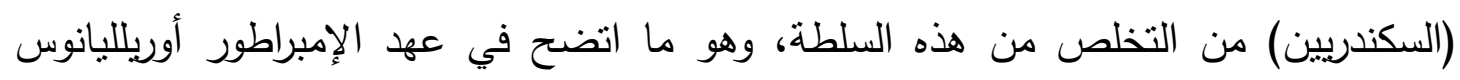

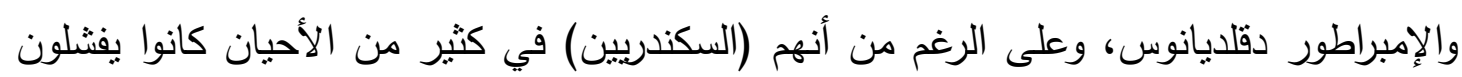

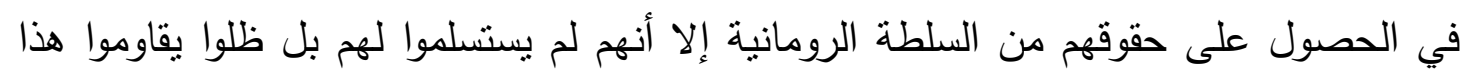
الحكم حتى النهاية. 


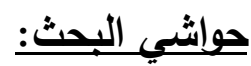

(1) عن موقعة أكتيوم البحرية التي انتصر فيها أكتافيوس القائد الروماني على كليوباترا وأنطونيوس وفتح مصر.

راجع: عبد اللطيف أحمد على؛ مصر والإمبراطورية الرومانية في ضوء الأوراق البردية، دار النهضة

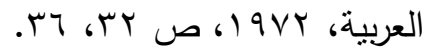

(Y) وحول لقب أغسطس الذي حصل عليه القائد أكتافيوس، راجع: سيد أحمد على الناصري، تاريخ الإمبراطورية

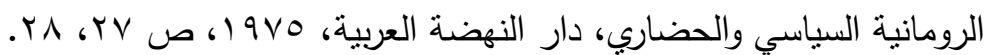

(r) رفض الإمبراطور أغسطس أن يصبح المصريون أعضاء في مجلس السيناتو في روما. راجع:

Dio Cassius, Roman History (L.C.L.), vol. 6, Book LI, Paragraph 17.

(₹)Robert, W. Smith, The Art of Rhetoric in Alexandria, its theory and practice in the Ancient World, The Hague, Netherlands, 2012, p. 21.

(0) عاش ديون كاسيوس في النصف الثاني من القرن بام وبداية القرن بام وتدرج في سلك الوظائف الرومانية

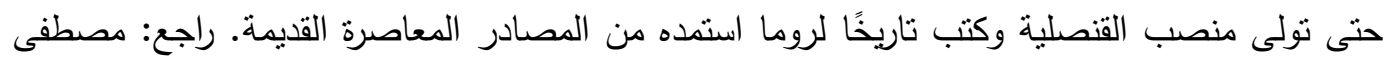

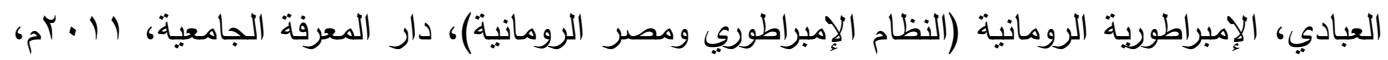

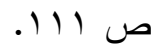

Dio Cassius, op. cit., vol. 6, Book LI, parag. 17.

Dio Cassius, op. cit., vol. 6. LI.

وعن زيارة الإمبراطور أغسطس للإسكندرية راجع: سيد أحمد على الناصري، المرجع نفسه؛ ص 9 (1؛ عبد

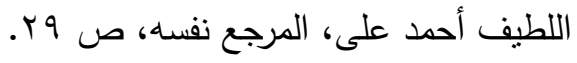

Dio Cassius, 6. LI.

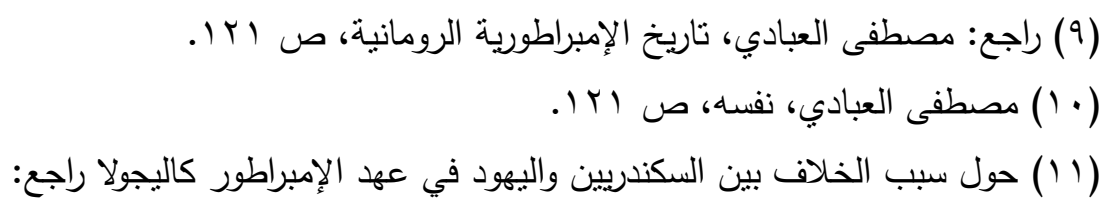

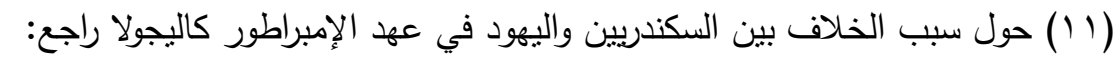

Sandra Gambetti, The Alexandrians Riots of 38. C. E. and the Persecution of the Jews: A historical Reconstruction, Leiden, Boston, 2009, pp. 213- 216.

Robert Smith, op. cit., p. 21.

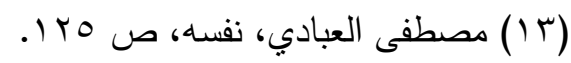

(ع () حول الخلاف بين السكندريين واليهود على مواطنة المدينة راجع: سيد الناصري، نفسه، ص ص ب ب I ا،

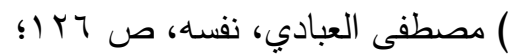

J. B. Bury, A history of the Roman Empire 27 B. C. to 180 A.D., Merkoba Press, 2017, no. page.

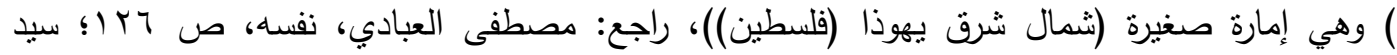

Barbara Levick, Claudius, Routledge, London, 2001, p. 184.

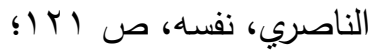

Sandra Gambetti, op. cit., p. 246.

(IV) وعن موقف الإمبراطور كاليجولا من اليهود راجع:

J. B. Bury, op. cit., no. page; Barbara Levick, op. cit., p. 184.

Musurillo, H. A., The Acts of the Pagan Martyrs, or Acta Alexandrinorum, Oxford, 1954, (9) (19) No. II; 
Sandra Gambetti, op. cit., p. 141.

$$
\text { مأخوذ (عن) مصطفى العبادي، المرجع نفسه، ص بr (1؛ راجع أيضًا: }
$$

Sandra Gambetti, op. cit., p. 138; Stephen, P., Kershaw, A brief history of the Roman Empire Rise ( $r \cdot$ ) and Fall, London, 2013, no page; Philo, Flaccum, 16-22.

Sam Wilkinson, Caligula, Routledge, London and New York, 2005, pp. 51, 84.

$$
\text { (YY) وكان الوفد اليهودي بزعامة فيلون والوفد السكندري بزعامة إيزيدور وأبيون. راجع: }
$$

Sam Wilkinson, op. cit., p. 51, 84.

$$
\begin{aligned}
& \text { (YT) وذهب أيضًا وفذًا من اليهود لمقابلة الإمبراطور كاليجولا وهو ما وردت الإثارة عنه في كتاب "سفارة إلى } \\
& \text { جايوس" للفيلسوف العبري فيلون والذي كان رئيسًا للوفد اليهودي حينذاك. راجع: }
\end{aligned}
$$

Filon, in Flaccum, ed by Legatio ad Gaiusm;

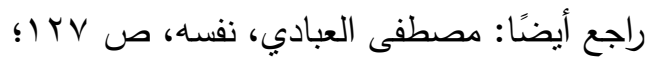

Michael Grant, The Climax of Rome, The final achievements of the Ancient World, AD. 161-337, Weidenfeld, London, 1993, p. 175.

$$
\text { وعن الإمبراطور كلاوديوس راجع: }
$$

Scramuzza, V. M., The Emperor Claudius, Harvard Univ. Press, 1940, p. 62.

(Yo) وقد عثر على بردية يونانية تحتوي على الرد الكامل لكلاوديوس وهو عبارة عن رسالة موجهة للسكندريين.

$$
\text { راجع: }
$$

Walter Ewing Crum \& Harold Idris Bell, The Jews and Christians in Egypt, Jewish Troubles in Alexandria and Athanasian Controversy, Oxford Univ. Press, 1924, pp. 5, 22, 27; Robert, W. Smith, op. cit., p. 79.

(T Y) قام الإمبراطور كلاوديوس من خلال رسالته التي وجهها للسكندريين بإعطائهم الأهمية الكاملة وعاملهم

Sandra Gambetti, op. cit., pp. 220- 221.

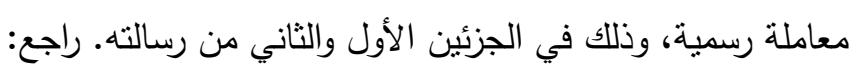

Barbara Levick, op. cit., p. (عن) Acta Alexandrinorum, II, 14-72.

(YV) لم يرضَ خطاب الإمبراطور كلاوديوس الذب أرسله للإسكندرية اليهود، والذي خاطب فيه السكندريين

$$
\text { بدرجة أكبر وبشكل رسمي عن موقف اليهود من خطاب كلاوديوس راجع: }
$$

Musurillo, H. A., The Acts of the Pagan Martyrs (Acta Alexandrinorum), Oxford, 1954, 18-26, 117-40 (ع) Sam Wilkinson, op. cit., p. 59.

Sandra Gambetti, op. cit., p.

$$
\begin{aligned}
& \text { (Y^) والمقصود من ذللك هو الحقوق السياسية راجع: }
\end{aligned}
$$

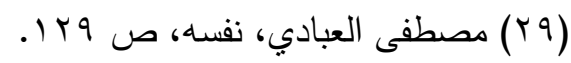

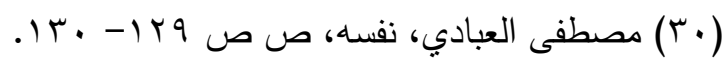

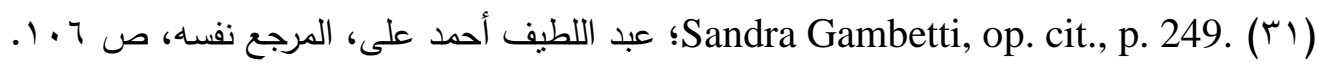

Barbara Levick, op. cit., p. 183.

Sandra Gambetti, op. cit., pp. 221-222.(عن) Acta Alex., II. 72- 82.

(ז) وعلى الرغم من ذللك فقد اتهم كلاوديوس بأنه استمع لجانب واحد فقط وهو السكندري ضد الجانب اليهودي

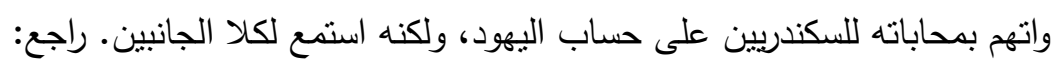

Barbara Levick, op. cit., p. 118.

Barbara Levick, op. cit., p. 81. 
Ibid., p. 184.

(rv) ونظرًا لتعثر الوصول إلى هذه البرديات فإننى استعنت بما ورد ذكره في كتاب د. مصطفى العبادي،

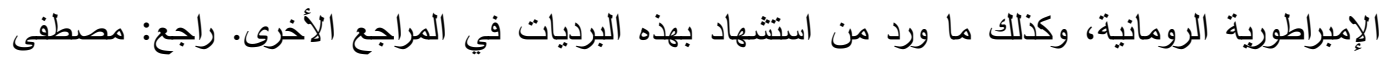

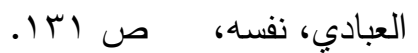

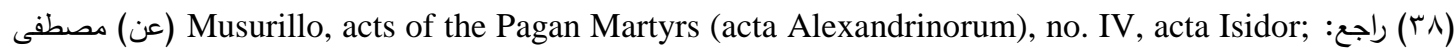

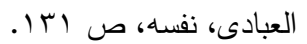

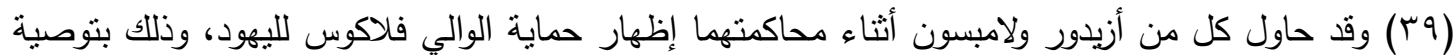

من الإمبراطور كاليجولا للوالي بأن يغض الطرف عن يهود الإسكندرية ـوهو ما فيه شك من الموقف

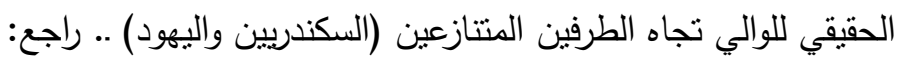

Sam Wilkinson, op. cit., p. 51.

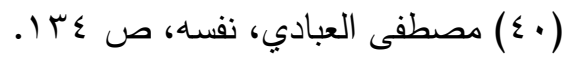

(1) عن ما قام به فسبسيانوس للتخلص من فيتيللوس والاستيلاء على عرش الإمبراطورية راجع: مصطفى

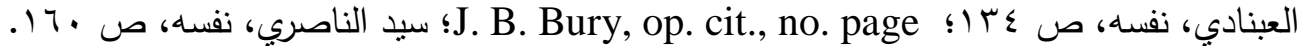

J. B. Bury, op. cit., no. page; ؛Dion Cassius, Roman History, vol. 8, LXV, 8.

Dion Cassius, op. cit., 8. LXV. 8.

Ibid., 8. LXV. 8.

Ibid., 8. LXV. 8.

Dion Cassius, op. cit., 8. LXV. 8.

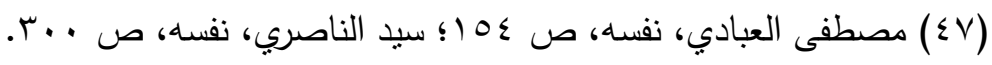

(\{^) ادعت الملكة زينوبيا ملكة تدمر أنها تتخرط من سلالة الملكة كليوباترا ملكة مصر وأن مدينة الإسكندرية

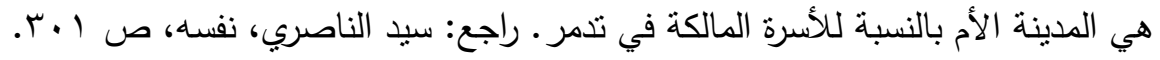

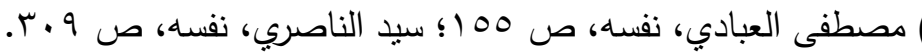

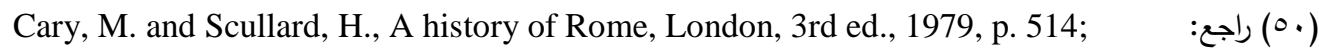
محمد السيد عبد الغني، ناريخ مصر تحت حكم الرومان، دار المعرفة لجامعية، الإسكندرية، ب991 (19 ص

$$
\text { Historia Augusta, Firmus (0 (0) محمد السيد عبد الغني، نفسه، ص AV) }
$$

Cary, M. \& Scullard, H., op. cit.,

Raoul MC Laughlin, Rome and the Distant East Trade Routes to the Ancient Lands of Arabia, Continuum, London and New York, 2010, p. 138.

Raoul MC Laughlin, op. cit., p. 138.

Jouguet, P., L'Egypte Greco-Romaine de la Conquéte d'Alexandre à Diocletien dans Précis (00) d'L'Histoire d'Egypte, Tome I, Le Caire, 1932, p. 404;

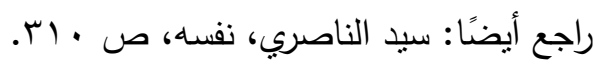

(1) أناطول هو سكندري المولد، وكان من أقدر العلماء في الفلسفة اليونانية، كالرياضة والهندسة والفلك والمنطق، وقد ترك الإسكندرية بعد انتهاء حصارها. راجع: يوسيبيوس القيصري، تاريخ الكنيسة، مكتبة

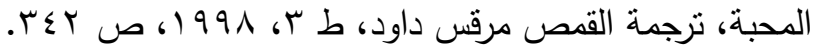




$$
\text { (ov) وعن المساعدات التي قدمها الأسقف أناطول للشعب السكندري المحاصر • راجع: }
$$

Eusibius, Historia Ecclesiastica, VII. 32.

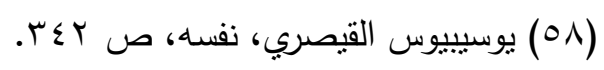

Seston, W., Diocletian, 1946, pp. 137 ff;

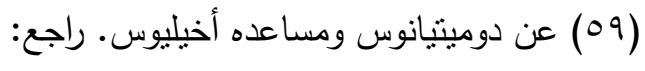

Cary, M. \& Scullard, H., op. cit., p. 518.

$$
\text { راجع أيضًا: }
$$

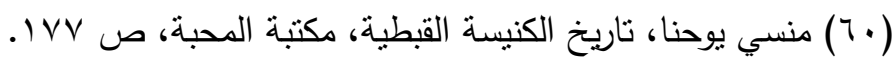
(آ) وعن حصار دقلديانوس لمدينة الإسكندرية راجع:

Bill Leadbetter, Galerius and the will of Diocletian, Routledge, 2011, no page.

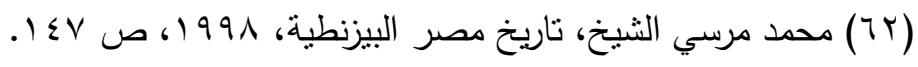

(Tr) هو عمود كورنثى من الجرانيت الوردي أقيم في الإسكندرية للإمبراطور دقلديانوس وكان تمثاله الضخم

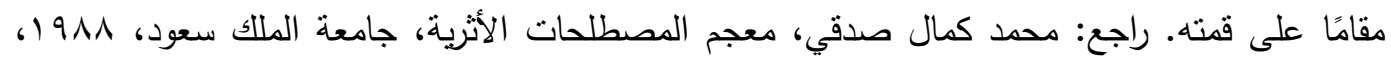

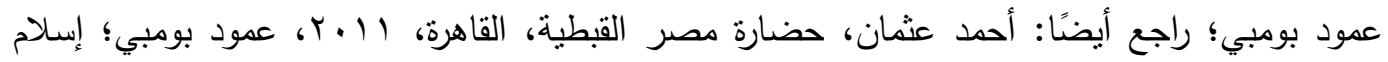

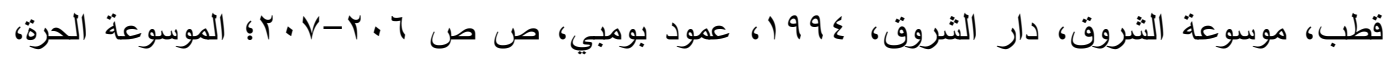
ويكيبيديا، عمود السوارى. موسوعه التروف، 